\title{
Representación de raza, clase y moral en la televisión del Perú. Un análisis social de "Magaly TeVe" y "Al fondo hay sitio"
}

\author{
Recibido: 19 noviembre de 2012 \\ Aceptado: 27 de junio de 2013 \\ Publicado: 29 de noviembre de 2013
}

\author{
Mario Sánchez Dávila \\ pccumsan@upc.edu.pe
}

Universidad Peruana de Ciencias Aplicadas

\begin{abstract}
Resumen: Este artículo se propone analizar la representación de raza, clase y moral en los programas televisivos "Magaly TeVe" y "Al fondo hay sitio" desde una mirada antropológica de la televisión, comprendiendo sus dimensiones comunicativas, discursivas y sociales. Por un lado, al analizar el discurso de "Magaly TeVe" fue fácil constatar que el porqué y el cómo del éxito de la estrategia comunicativa de este fenómeno televisivo aludían estrechamente a códigos morales socialmente compartidos y a un modo configurado de organización, relación e interacción ya validados en nuestro tejido social.
\end{abstract}

Por otro lado, al examinar el discurso de "Al fondo hay sitio" fue sencillo comprobar que hemos confundido, ingenuamente, inclusión con eventuales redenciones dentro de un marco de convergencia espacio-temporal de dos códigos culturales contradictorios y que permanentemente se relacionan e interactúan desde directrices de raza y clase que funcionan como núcleos semánticos que configuran, por un lado, la construcción narrativa y, por el otro, una determinada relación e interacción social de poder y violencia simbólica entre sus personajes.

Palabras clave: Antropología, comunicación, discurso, semiología, sociedad, televisión.

Abstract: This article proposes to analyze the representation of race, class and moral in television phenomena "Magaly TeVe" and "Al fondo hay sitio" from an anthropological glance of the television, and understanding their communicative, discursive and social dimensions. On one hand, after analyzing the discourse of "Magaly TeVe", it was easy to see that the why and how the success of the communication strategy for this television phenomenon closely imposes moral and socially shared codes, and a configured mode of organization, relationship and interaction already validated in our social fabric. 
On the other hand, after analyzing the discourse of "Al fondo hay sitio", it was easy to see that we have confused, naively, inclusion with redemption within a framework of convergence space-time of two contradictory cultural codes that permanently relate and interact from guidelines of race and class that function as semantic cores that shape, on the other hand, a determined social relationship and interaction of power and symbolic violence between his characters.

Key words: Anthropology, Communication, Discourse, Semiology, Society, Television.

\section{Introducción}

Hay que tener una manera efectiva de afrontar la disciplina antropológica para los mundos contemporáneos. En ese sentido, lo que nos interesa es presentar un modo (propio pero, por supuesto, no el único) de ser/estar/hacer antropología hoy en día. Fragmentos de una línea de antropología posestructural: una propuesta específica que parte de la redefinición de elementos epistemológicos del proyecto antropológico estructuralista.

Los alcances de este artículo, pues, deben ser reconocidos dentro de la línea de estudios semiológicos y antropológicos denominada como media anthropology. Pero también dentro de los estudios de la comunicación y del análisis social del discurso. Porque, finalmente, un análisis de la representación de raza, clase y moral en los fenómenos televisivos "Magaly TeVe" y "Al fondo hay sitio" no sólo requiere de un acercamiento antropológico hacia la televisión, sino también de la comprensión de sus dimensiones comunicativas, discursivas y sociales.

\section{Mito y ritual en la televisión del siglo XXI}

Utilizando una de las varias conceptualizaciones sugeridas por Barthes (2009), el mito debe ser entendido como un sistema de comunicación y significación. Por ello,

"todo lo que justifique un discurso puede ser mito. [...] Todo puede ser un mito. [...] Cada objeto del mundo puede pasar de una existencia cerrada, muda, a un estado oral, abierto a la apropiación de la sociedad. [...] Lejana o no, la mitología sólo puede tener fundamento histórico, pues el mito es un habla elegida por la historia: no surge de la 'naturaleza' de las cosas. Este habla es un mensaje y, por lo tanto, no necesariamente debe ser oral; puede estar formada de escrituras y representaciones: el discurso escrito, así como la fotografía, el cine, el reportaje, el deporte, los espectáculos, la publicidad, todo puede servir de soporte para el habla mítica" (Barthes, 2009: 199-200).

En esa línea, "algunos objetos se convierten en presa de la palabra mítica durante un tiempo, luego desaparecen y otros ocupan su lugar, acceden al mito" (ibídem: 200), porque es cierto que un mismo mito no dura para siempre, pues 
"los mitos se transforman. Estas transformaciones que se operan de una variante a otra de un mismo mito, de un mito a otro mito, de una sociedad a otra sociedad para los mismos mitos o para mitos diferentes, afectan ora la armadura, ora el código, ora el mensaje del mito, pero sin que este deje de existir como tal; respetan así una suerte de principio de conservación de la materia mítica, en los términos del cual de todo mito podría siempre salir otro mito [...] O bien se desvanecería para ceder el puesto a otros mitos, característicos de otras culturas o de otras regiones; o bien, para subsistir, sufriría alteraciones que afectasen no ya solamente la forma, sino inclusive la esencia mítica [...] Así, un mito que se transforma pasando de tribu en tribu se extenúa al fin sin desaparecer por ello" (Lévi-Strauss, 2011: 242, 248 y 253$)$.

De esta manera, el mito se transforma. Muere en el espacio, pero no en el tiempo. Por eso se puede afirmar que hay mitos eternos. Mitos que dramática, tópica y morfológicamente se pueden entender como eternos. Y es que si pensamos diacrónicamente (esto es, el fenómeno no a través del tiempo y del espacio, lo que sería nada más que un análisis histórico, sino a través de los tiempos y los espacios, lo que sería ya un análisis etnológico) es posible encontrar, entre la vasta diversidad cultural, patrones estructurales, tales como los narrativos (el melodrama, la tragedia, la comedia, la sátira, la épica y el melodrama), los tópicos (el enfrentamiento, la muerte, la burla, la hierofanía, la celebración y la búsqueda) y las formas (los chismes, el humor, los crímenes, las noticias, la heroicidad, las fantasías, los premios, los juegos, las situaciones, el realismo y las ficciones) similares que aparecen y se repiten en los relatos de diversas sociedades del mundo, aparentemente, disímiles unas de otras, como lo han demostrado ya los estudios de la magia, de la religión y de la mitología comparada (Frazer, 2011; Graves, 2000 y 2002; Dumézil, 1968, 1971 y 1973), de la folklorística y los personajes arquetípicos (Propp, 1987; Thompson, 1955) y de la historia de las religiones (Eliade, 1996), como lo demostraría seguramente un estudio diacrónicoestructural de los mitos televisivos propios de los mundos mediáticos contemporáneos. Así, pues, podemos estar seguros de que existen ciertas

"figuras arquetípicas, formas arquetípicas, modelos ejemplares que han ayudado a estructurar y dar forma a las historias entre las culturas y las épocas. Los arquetipos son figuras y fuerzas fundamentales, como los héroes, las inundaciones, los villanos, las plagas, los patriarcas, las parias, buenas madres, embaucadores. Otorgándole vida a la narrativa, ellos ayudan a crear la primaria historia arquetípica que se encuentran en el corazón de la narrativa humana" (Lule, 2005: 102).

Además, “¿es una simple coincidencia (y causas diferentes explican que, aquí y allá, aparezcan arbitrariamente reunidos los mismos motivos) o la analogía atañe a razones más profundas?" (Lévi-Strauss, 2011: 25). Ello implica, por lo tanto, ya la posibilidad de identificar elementos estructurales, compartidos y repetitivos en diversos productos televisivos a lo largo de los tiempos y de los espacios, brindando al investigador luces sobre un fenómeno mucho más amplio y susceptible de ser analizado, en perspectiva global y por 
comparación diacrónica, y ya no únicamente como un fenómeno particular y aislado. Y es que, como sabemos, "todo mito es por naturaleza una traducción [...] se sitúa, no en una lengua y en una cultura o subcultura, sino en el punto de articulación de estas con otras lenguas y otras culturas. El mito no es nunca de su lengua, es una perspectiva sobre otra lengua" (Lévi-Strauss, 2000: 576-577). Y es que

\begin{abstract}
"todo mito es una versión de otro mito, todo otro mito se abre sobre un tercer y un cuarto mito [...] Si el mito es traducción, es porque sobre todo no es representación, porque una traducción no es representación, sino una transformación. [Es decir] todo 'grupo' de mitos termina por encontrarse en la intersección de un número indeterminado de otros grupos; y en cada grupo, cada 'mito' es igualmente una interconexión; y en cada mito [...] Los grupos deben poder cerrarse; pero el analista no puede dejarse encerrar en ellos" (Viveiros de Castro, 2009: 222-227).
\end{abstract}

Tomando en cuenta dicha advertencia, vale señalar las investigaciones académicas de Berkowitz (1992, 2000 y 2005) sobre las noticias de ocurrencia improbable que detentan una venerada atención social; la de Martín-Barbero (1992) sobre el melodrama; la de Imbert (2003) sobre el espectáculo y los nuevos rituales comunicativos; la de La Pastina, Rego y Straubhaar (2004) sobre la centralidad de las telenovelas en la vida cotidiana de América Latina; la de Schudson (2005) sobre las noticias o news stories como relatos, historias o narraciones; la de González Requena (1988) con sus repertorios escópicos de los concursos, los deportivos, las entrevistas, los dramáticos, los docudramas y los informativos y los telefilms del espectáculo televisivo; la de Martín-Barbero y Rey (1999) con sus géneros televisivos y sus formatos industriales; la de Thussu (2007) con el infoentretenimiento de los talk shows, reality shows, schockumentales y recreaciones, con los programas informativos de la realidad, como los noticieros, dominicales, reportajes documentales; de ficción, como las series, los sitcoms, las películas y las telenovelas; y la de las mismas consultoras de marketing, con los noticieros-informativos, películas, telenovelas, dibujos animados, periodístico-político, deportivos, culturales, musicales, cómicos, espectáculos-farándula, miniseries, concursos y series de humor-comedias. Cada uno de ellos, como otros, tiene diversas razones (ideológicas, coyunturales, mercantiles) para sus categorizaciones.

Pero, aquí, lo verdaderamente importante es constatar cómo los trabajos de estos y muchos otros investigadores nos permiten comprender que, dentro de los estudios sobre las cosmologías mediáticas, se ha desarrollado ya, de modo implícito aunque no necesariamente ordenado, una suerte de consenso argumental, sobre lo que se podría denominar mitología mediática, porque patrones estructurales narrativos, tópicos y morfológicos, "en apariencia arbitrarias, se reproducen con los mismos caracteres, y ocasionalmente con los mismos detalles, en las diversas regiones del mundo" (Lévi-Strauss, 1997: 231). Pero, ¿acaso eso nos permite argumentar que los mitos arquetípicos han adoptado nuevas formas en los relatos contemporáneos?, pues

"los editores y reporteros no tienen que concebir nuevas historias para cada evento. Ellos no tienen que contar historias nunca antes escritas o 
leídas [...] Lo toman de narrativas compartidas. Dibujan a partir de formas tradicionales de historias [...] La historia no cambia en algo completamente nuevo y nunca antes visto, sin embargo. Esa cambia en otra fundamental y familiar historia. [Y es que] como los mitos, las noticias [como el resto de los mitos mediáticos] no son realmente nuevas [...] Las noticias nos dicen las mismas historias una y otra vez. Como el mito, las noticias [como el resto de los mitos mediáticos] nos dicen solamente lo que pasó ayer pero lo que ha pasado siempre. Inundación y fuego, desastre y triunfo, crimen y castigo, tormenta y sequía, muerte y nacimiento, victoria y derrota diariamente, las noticias han recontado y recontarán estas historias" (Lule, 2005: 101 y 105).

En otras palabras, ¿podríamos argumentar que la estructura mitológica matriz (que se encontraría más allá de los tiempos y los espacios, es decir, inconsciente dentro de las estructuras mentales del pensamiento universal, si es que es posible todavía admitir semejante postulado chomskiano) actualiza patrones estructurales narrativos, tópicos y morfológicos, adoptando nuevas formas en las historias de la contemporaneidad?

Nos explicamos mejor. Los mitos de todos los tiempos y las épocas (viéndolos desde sus patrones estructurales narrativos, tópicos y morfológicos) comparten, universal e inconscientemente, características germinales en común entre ellos. Sin embargo, nos engañaríamos, inocentemente, y este artículo terminaría aquí y ahora si admitimos que el sistema de producción mediática se encuentra, por entero, basado en (y tiene la función de remplazar, reproducir y hacer circular mitos de) una matriz mitológica que preexiste en el inconsciente universal del pensamiento. $\mathrm{Y}$, quedaríamos atrapados en las necesarias pero insuficientes redes tejidas por el formalismo, reduciendo, limitando y empobreciendo, por lo tanto, nuestro objetivo de estudio: el acercamiento antropológico hacia "Magaly TeVe" y "Al fondo hay sitio", comprendiendo, a través de sus discursos, sus dimensiones sociales y comunicológicas, dimensiones que (desde nuestro juicio es preevidente) explican mucho mejor el éxito de ambos fenómenos televisivos. Y, precisamente por ello, es que se vuelve imposible conformarse

"con un análisis puramente formal: este análisis constituye una etapa preliminar de la investigación, fecunda en la medida en que permite formular, en términos más rigurosos que los habituales, problemas de geografía y de historia [...] En mitología como en lingüística, el análisis formal plantea inmediatamente una cuestión: el sentido" (Lévi-Strauss, 1997: 260).

Así, pues, volviendo con Viveiros de Castro (2009), ¿un estructuralismo sin estructuras? Mejor todavía: un (post)estructuralismo preocupado por otra noción de estructura. Un (post)estructuralismo que reconoce la existencia de innumerables estructuras y que no admite la existencia de una estructura de las estructuras. Un (post)estructuralismo que ya no está obstinado cerradamente en la búsqueda de estructuras elementales, sino que está abiertamente preocupado por la búsqueda de elementos estructurales. Un (post)estructuralismo que no piensa la sociedad y la cultura a partir de las estructuras, sino que piensa las estructuras a partir del estudio de la sociedad y la cultura. Un (post)estructuralismo (un 
neo-lévi-straussismo o, si se prefiere, un lévi-straussismo no ortodoxo) que supera la dicotomía oposicional entre las teorías objetivistas de las prácticas sociales determinadas por estructuras sociales y agencialidad neutralizada del sujeto visto como soporte y las teorías subjetivistas de las prácticas sociales determinadas por acciones individuales. En otras palabras, un (post)estructuralismo que

\begin{abstract}
"no tiene nada que ver con el árbol, sino con el rizoma: es una gigantesca tela sin centro ni origen, un megaagenciamiento colectivo e inmemorial de enunciación dispuesto en un 'hiperespacio' (Lévi-Strauss, 1967: 84) incesantemente atravesado por 'flujos semióticos, flujos materiales y flujos sociales' (Deleuze y Guattari, 1980: 33-34); una red rizomática recorrida por diversas líneas de estructuración, pero que, en su multiplicidad interminable y su contingencia histórica radical, es irreductible a una ley unificadora e imposible de representar por una estructura arborescente" (Viveiros de Castro, 2009: 222).
\end{abstract}

Debido a que los estudios de la media anthropology no se pueden contentar, desde una perspectiva diacrónica, con una ambiciosa aunque necesaria búsqueda de patrones estructurales (dramáticos, tópicos y morfológicos) que fundamentan las historias arquetípicas de nuestra humanidad, creemos que la misión de esta disciplina para el siglo XXI es investigar, desde una perspectiva sincrónica (esto es, el fenómeno en un tiempo y un espacio determinado), los fenómenos mediáticos, en tanto sistemas de comunicación, atendiendo a los códigos con los que estos son construidos (y, por eso, estudiarlos) para comprenderlos desde sus dimensiones sociales y culturales.

\title{
3. Televisión, mito y sociedad. Recuperando el sentido
}

Uno de los mayores errores de quienes se han aproximado al estudio de los fenómenos televisivos y, particularmente, al estudio de "Magaly TeVe" y de "Al fondo hay sitio" ha sido privilegiar lecturas valorativas de desaprobación en vez de intentar comprender sus dimensiones socio-comunicológicas para buscar el sentido social en sus mismos discursos. Este artículo es producto de este reclamo. Y atendiendo a este reclamo, y consecuentemente al rigor académico, nuestro punto de partida fue la preocupación semiológica por el sentido. Y, precisamente por ello, preocupación por la metodología de acercamiento, por la epistemología de contacto, para con nuestros supuestos sujetos-objetos de estudio, para con el fenómeno que pretendíamos analizar insertándolo en su dimensión social. Preocupación que nos obligó, pues, a comprometernos en dejar de lado la interpretación (lo que nosotros pensamos, prejuiciosa y apocalípticamente) y de enrumbarnos en la búsqueda del sentido en el discurso.

"El investigador debe evitar el egocentrismo, es decir, el análisis y la evaluación de hechos [...] desde el punto de vista de sus propios hábitos [...] y de sus normas [...] que constituyen la base de su formación. [...] no debe proyectar en el pasado este hecho con su aspecto transformado, sino que debe restaurarlo en su función originaria, en el marco del sistema en cuyo seno había nacido" (Círculo Lingüístico de Praga, 1970: 42). 
Por ello, resultó indispensable olvidarnos del "nosotros", del fácil "pienso" y buscar lo que los textos dicen en sí mismos. Para no hablar de nosotros mismos, sino del fenómeno a analizar. Para no construir un discurso paralelo que ponga entre paréntesis lo dicho por el fenómeno. Para no privilegiar lo que nosotros queremos ver, describir e interpretar. Y sí para dirigir nuestra mirada a lo que el fenómeno dice y plantea en su acción discursiva; la mención o la referencia que hace; su enunciación y su proposición. Y no la intención consciente o inconsciente de su hacer, ni mucho menos el origen profundo e individual de su impulso a significar. Así, leer antes que interpretar. Y leer el sentido del discurso implica reconocer que

"ya la lingüística nos enseña desde hace mucho tiempo que los elementos significativos de un discurso se integran en un sistema, que tienen valor respecto a él, y que en ese sentido el discurso lleva en sí mismo las claves para su comprensión [...] las palabras de un mensaje no se han juntado por casualidad, sino para la búsqueda de un sentido y que, por tanto, dicho sentido no debemos buscarlo en el diccionario o en el código general de la lengua, sino en el código de ese discurso [...] la valoración de un código como instrumento de regulación social de la conducta implica adscribirlo a códigos de idéntica naturaleza que opera en una sociedad" (Biondi y Zapata, 2006: 98 y 108).

Leer, entonces, el fenómeno dentro del marco del sistema donde ha sido concebido. Y, para ello, necesitamos categorías de análisis: metalenguaje antropológico, abstracción metodológica, conceptualización científica, artefacto teórico, medio arbitrario para apropiarnos, ordenar y comprender los mecanismos fundamentales de una realidad fenomenológica. Pero nuestras categorías de análisis no pueden ni deben ser ajenas ni injustas al sistema que, como investigadores, entraremos a intentar discurrir sus elementos esenciales. Pueden y deben ser categorías analíticas que nos permitan comprender mejor la presencia y permanencia de los programas televisivos "Magaly TeVe" y "Al fondo hay sitio" dentro de la vida social. Y es que

"la condición humana sólo puede abordarse en términos de organización social. [Porque] el hombre sólo se piensa en plural. Toda reflexión sobre el hombre es social [...] la especificidad del punto de vista antropológico reside en este interés central por el estudio de la relación con el otro tal como esta se construye en su contexto social. La cuestión del sentido, es decir, de los medios con que los seres humanos que habitan un espacio social se ponen de acuerdo sobre el modo de representarlo y de actuar sobre él, es el horizonte de las actividades antropológicas" (Augé y Colleyn, 2004: 18-19).

Pero, ¿por qué reconstituir y utilizar categorías como mito y ritual es pertinente para el análisis socio-comunicológico del "sentido" en el discurso de "Magaly TeVe" y de "Al fondo hay sitio"? Porque, como parte de un aparato coherente, exhaustivo y simple, siguiendo el principio empírico de Hjelmslev (1943), las categorías "mito" y "ritual" facilitan la separación entre lo implícito y lo explícito, el contenido y la expresión, la sustancia y la 
forma, la langue y la parole, el código y el texto, el sistema y el proceso, el metalenguaje y el lenguaje, respectivamente.

"[Y es que el mito y el ritual] se completan en dominios que exhiben ya un carácter complementario. El valor significante del ritual aparece acantonado en los instrumentos y en los gestos: es un paralenguaje. En tanto que el mito se manifiesta como metalenguaje: hace uso pleno del discurso, pero situando las oposiciones significantes que le son propias en un grado más alto de complejidad que el requerido por la lengua cuando funciona con fines profanos" (Lévi-Strauss, 2011: 67).

Pero no cualquier producto televisivo puede ser entendido como un fenómeno televisivo, y, mucho menos, como un mito. Únicamente aquellos que detenten considerables índices de rating. Porque el rating nos dice que dicho fenómeno televisivo es foco colectivo de atención social (Silverstone, 1988). Porque, para ser tratado como fenómeno televisivo (y, todavía más, como un mito), un producto televisivo tiene que ser un producto social. En otras palabras, tienen que tener cierto grado de convencionalidad, un carácter colectivo. Y tampoco nos engañemos. No estamos afirmando que un fenómeno televisivo sea un mito. Estamos afirmando que un fenómeno televisivo puede tratarse como si fuera un mito. No porque lo sea, sino porque (enfocándonos en sus vertebraciones sociales) se pueden esclarecer los mecanismos fundamentales con los que fue construido.

Por ello, "la investigación antropológica puede develar ciertas secuencias míticas o revelar funciones y lógicas similares a las del pensamiento y creación mítica" (Rothenbuhler y Coman, 2005: 113). Y a esto se debe el reclamo de considerar el mito en tanto aislado de sus manifestaciones individuales, y de concentrarnos en el plano colectivo del fenómeno televisivo y en sus dimensiones socioculturales, es decir, en el plano de una vida social ya consolidada. De esta manera, las categorías mito y ritual nos permitieron atender a lo permanente y comprender mejor la presencia y permanencia de los fenómenos televisivos "Magaly TeVe" y "Al fondo hay sitio" dentro de nuestra sociedad.

Atendiendo a nuestro reclamo, hemos esquematizado los siguientes cuadros:

Figura 1: Categorías de análisis - "Magaly TeVe".

\begin{tabular}{|c|c|c|c|}
\hline & \multicolumn{3}{|c|}{ MAGALY TEVE } \\
\cline { 2 - 3 } & RITUAL & MITO \\
\hline 2. SEGUNDO SISTEMA & Expresión & Contenido \\
\hline & Chisme y escándalo & Sustancia & Forma \\
\hline
\end{tabular}

Fuente: Elaboración propia. 
Figura 2: Categorías de análisis - "Al fondo hay sitio".

\begin{tabular}{|c|c|c|c|}
\hline & \multicolumn{3}{|c|}{ AL FONDO HAY SITIO } \\
\hline & RITUAL & \multicolumn{2}{|c|}{ MITO } \\
\hline & Expresión & \multicolumn{2}{|c|}{ Contenido } \\
\hline \multirow[t]{3}{*}{ 2. SEGUNDO SISTEMA } & Poder y violencia & Sustancia & Forma \\
\hline & & Distinción y distancia & Raza y clase \\
\hline & & \multicolumn{2}{|c|}{ 1. PRIMER SISTEMA } \\
\hline
\end{tabular}

Fuente: Elaboración propia.

En otras palabras, el mito es el contenido que opera a nivel metalingüístico y el ritual es la expresión (de dicho contenido mítico) que opera a nivel lingüístico. Porque el ritual es el mito en acción. El mito ubicado en el plano implícito, mientras que su ritual (la puesta en escena del mito) en el plano explícito. Por lo tanto, consideramos los fenómenos televisivos "Magaly TeVe" y "Al fondo hay sitio" como mitos. Pero mitos, siguiendo a Barthes (2009), en tanto "sistemas semiológicos segundos". ¿Por qué?

"El mito es un sistema particular por cuanto se edifica a partir de una cadena semiológica que existe previamente: es un sistema semiológico segundo [...] existen en el mito dos sistemas semiológicos de los cuales uno está desencajado respecto del otro: un [primer] sistema lingüístico [...] que llamaré lenguaje objeto [la vigilancia y el castigo / la distinción y la diferencia como sustancias y la moral / la raza y la clase como formas], porque es el lenguaje del que el mito se toma para construir su propio sistema [su propio contenido]; y el mito mismo ['Magaly TeVe' / 'Al fondo hay sitio'], que llamaré metalenguaje porque es una segunda lengua en la cual se habla de la primera" (Barthes, 2009: 205-206).

Entonces, si pensamos los fenómenos televisivos "Magaly TeVe" y "Al fondo hay sitio" desde la categoría mito, ¿qué estamos buscando? El mito es un reflejo de la estructura social y de las relaciones sociales (Lévi-Strauss, 1997) y un sistema de operaciones lógicas que operan mediante varios códigos sociales y culturales (Lévi-Strauss, 2008). El mito nos enseña mucho sobre la sociedad en la que ha sido concebido, nos ayuda a exponer los resortes íntimos del funcionamiento social (Lévi-Strauss, 2000). Por ello, el

"mito como máquina de sentido: un instrumento para convertir un código en otro para proyectar un problema sobre un problema análogo, para hacer 'circular la referencia' (diría Latour), contra-efectuar el sentido en forma anagramática” (Viveiros de Castro, 2009: 222-223).

Referencia a formas de obrar, pensar y sentir exteriores al individuo y dotados de un poder coacción externo en virtud del cual estos se imponen. Organizaciones definidas. Maneras de ser. Maneras de hacer ya consolidadas colectiva y socialmente. Durkheim (1986) habla- 
ba de reglas y de estructuras. Aquí preferimos hablar de núcleos semánticos, como la moral, la raza y la clase, no como estructuras elementales, sino como (sin duda, no los únicos) elementos estructurales. Signos que, dentro de una sociedad, son patrones de conductas de grupos sociales. Ya Jakobson (1956) nos enseñaba que bajo los procesos de comunicación hay códigos o sistemas de significación:

“Cuando los requisitos para la ejecución del proceso se reconocen socialmente y preceden al propio proceso, entonces dichos requisitos deben considerarse como reglas (y, efectivamente, son reglas de competencia procesal) [...] los síntomas de significados (en cuanto unidades culturales que se convierten en contenidos de posibles comunicaciones) están organizados en estructuras (campos o ejes semánticos) que siguen las mismas reglas semióticas descubiertas por los sistemas de significantes" (Eco, 1986: 25 y 51).

No obstante, estas propiedades míticas sólo pueden ser buscadas a través del nivel habitual de expresión lingüística, a través de la categoría ritual. Por ello, si pensamos los fenómenos televisivos "Magaly TeVe" y "Al fondo hay sitio" desde la categoría ritual, ¿qué buscamos? El ritual es un conjunto de acciones simbólicas que comunican tanto información como la posición de los individuos dentro de un sistema total de comunicación a otros individuos de la misma y determinada estructura $u$ orden social. El ritual comunica el "estatus del individuo en cuanto persona social en el sistema estructural en el que se encuentra en el momento actual" (Leach, 1976: 33). El ritual es central para la comprensión de un modo de ver y estar en un respectivo universo social. El ritual como una expresión de lo social (Turner, 1980).

Pero, hablando metodológicamente, ¿cómo accedimos al ritual y, posteriormente, al mito? A través de la reconstrucción de la mención y de las subyacencias de lo dicho. Nuestro asunto era, definitivamente, con el discurso. Materia, pues, que compartimos con la sociolingüística. Porque nos parece claro que a través del lenguaje accedemos a categorías sociales y a realidades, mentalidades e imaginarios. Y, precisamente por ello, admitimos que

"toda producción de sentido es necesariamente social: no se puede describir ni explicar satisfactoriamente un proceso significante sin explicar sus condiciones sociales productivas [...] [Y estas] solo se puede develar cuando se considera la producción de sentido como discursiva. Por lo tanto, sólo en el nivel de la discursividad el sentido manifiesta sus determinaciones sociales" (Verón, 1987: 126).

En conclusión, a través del lenguaje como hecho social por excelencia (Lévi-Strauss, 2011). Del lenguaje como aspecto integral de la vida social. Del lenguaje como vehículo primario para la interacción de los miembros de una sociedad. Del lenguaje, finalmente, como el facilitador de producción y reproducción de lógicas de pensamiento y de acción colectivas. Pero no reivindiquemos únicamente la importancia de realizar un análisis inmanente (lo que el fenómeno plantea en su discurso), sino también la importancia de realizar un análisis sincrónico (el fenómeno en un momento dado), pues necesitamos un análisis 
que apele a espacios y tiempos socioculturales particulares dentro de los cuales los fenómenos televisivos "Magaly TeVe" y "Al fondo hay sitio" son deconstruidos con la finalidad de comprender el por qué y el cómo de su presencia y permanencia dentro de nuestra sociedad. Para comprender el conjunto, y no sólo el acontecimiento. Para mirar el bosque, y no sólo el árbol. En definitiva, como decía Spitzer (1961), para adivinar el todo.

\section{Miradas que vigilan, imágenes que castigan. Chisme, moral y discurso social en "Magaly TeVe"}

El fenómeno televisivo "Magaly TeVe" (1997-2012) ha sido uno de los pocos programas televisivos más vistos a nivel nacional y que más duración ha tenido a lo largo de la historia de la televisión peruana ${ }^{1}$. Este hecho convocó nuestra curiosidad intelectual. Y, cuando nos sumergimos en el discurso de "Magaly TeVe", fue fácil constatar (algo que no han hecho los pocos académicos que se aproximaron al análisis de "Magaly TeVe" y que sí hacemos aquí) que el porqué y el cómo del éxito de la estrategia comunicativa de este fenómeno televisivo aludían estrechamente a códigos morales socialmente compartidos y a un modo configurado de organización, relación e interacción ya validados en nuestro tejido social. Empecemos, entonces, a argumentar nuestra propuesta.

\subsection{La presentación de la persona y del personaje en la vida mediática}

Magaly Medina Vela nació en Huacho (1963) bajo el seno de una familia humilde, estudió periodismo en la Escuela Jaime Bausate y Mesa y se casó y divorció del periodista César Lengua, aunque, para aquel entonces, ya tenía a quien hasta ahora es su único hijo (Gianmarco Mendoza Medina) producto de un fugaz matrimonio en su tierra natal. Magaly Medina ha pasado por los segmentos de locales, policiales y espectáculos del diario Correo.

1 El consumo del programa "Magaly TeVe" atravesó (desde su aparición en 1997) con una relativa continuidad (y a pesar de sus altos y bajos) en cada NSE, englobando el conjunto de la sociedad limeña y sus niveles socioeconómicos (IGM, IPSOS-APOYO, Opinión y Mercado, 1997-2011). Así, aunque el sector que más ha sintonizado, en promedio, el programa se encuentra en el NSE C, el consumo de los demás NSE tampoco se encuentra tan alejado del promedio. Este dato es relevante si aceptamos que el target principal del programa son las amas de casa y los jefes del hogar (IBOPE TIME, 2010). También podemos señalar que, en promedio, quienes más sintonizan el programa son personas de entre 25 y 39 años de edad, pero, como sucede con el consumo por NSE, la sintonía en las personas de otras edades (sobre todo en las de 40 a 55 años y las de 55 a 70 años) tampoco se encuentra alejada de las que (por rango de edades) más sintonizan "Magaly TeVe" (IGM, IPSOS-APOYO, Opinión y Mercado, 1997-2011). A pesar de los numerosos e infructíferos intentos de imitación (no sólo en medios televisivos, que copian el estilo lingüístico del programa y su forma particular de ser conducido, sino también en otros medios periodísticos, que comenzaron a expandir sus secciones referidas al espectáculo y a darle más espacios a difundir los ampays de "Magaly TeVe"; los ataques, las campañas masivas y las cruzadas mediáticas por sacar del aire al programa; presiones legales, mayores controles de mesura) después de quince años en el aire, "Magaly TeVe" fue uno de los programas televisivos que más duración ha tenido a todo lo largo de la historia de la televisión peruana (sin contar, por supuesto, al programa "Trampolín a la fama", conducido por Augusto Ferrando) y una sintonía que se llevó, siempre en su horario de 21:00 a 22:00 horas, la mayor audiencia televisiva y el mayor puntaje en el índice de rating (ibídem). 
Estuvo en la revista Oiga, donde aportaba semanalmente una crítica sobre la televisión local. Apareció en el programa de televisión "Fuego Cruzado".

Pero la figura de Magaly Medina ha quedado en el pasado, pertenece a una etapa olvidada o íntima de la misma. La Magaly Medina que nos interesa es la pública, la que performa y proyecta una imagen simbólica a través de un juego, pensado, calculado o no, de signos en escena. Así, pues, mientras Magaly Medina (como persona íntima y natural) no socializa abiertamente y se recluye en espacios clandestinos, Magaly Medina (como personaje televisivo, público, mediático) se burla y chismea incluso hasta de sí misma.

Hablemos, entonces, del personaje de Magaly Medina en la esfera pública que juega un rol donde se representa a sí misma y donde su personaje tiene el mismo nombre y apellido que el de su persona. Por recordar sólo algunos incidentes, se quitó el calzón (uno falso, según señaló la misma Magaly Medina) mientras bailaba en el escenario al ritmo del grupo loretano Euforia; y que

“estando en el 9 [ATV] instaló un buzón de chismes y un 'hate-mail' (correo de odio) a lo Howard Stern -había que pagar para insultarla- que le permitió mirar a distancia y reír con su rol de bruja o, más bien, de 'urraca', citando el apelativo que hizo suyo hasta el punto de adoptar de mascota inerte y amuleto a un muñeco urraquiento que nunca la abandona [...] Se puso traje a rayas cuando perdió la primera instancia de su primer juicio por difamación; se quitó el calzón ante la Chola Chabuca; se vistió de negro para mofarse del divorcio de Gisela y de blanco para escarnio de la felicidad ajena; se vistió de basurera pues alguien le dijo que era 'la baja policía de la televisión'; condujo un programa en plena borrachera y, a fines de 1998, se otorgó a sí misma un premio por el 'papelón del año'; y todo esto con pleno dominio del exceso, encauzando la travesura en un programa cuyos límites ha ido conociendo cada vez mejor" (Vivas, 2008: 487).

Estamos, pues, frente a la personificación del chisme, donde ella define, lleva la pauta, del formato mismo en el que ella se ha encasillado. De este modo,
“estamos ante un estilo de programa personificado por su conductora, con nombre propio. Ella es la representación del chisme como formato televisivo, llevado a su profesionalización. Ahora es posible ser famosa y dirigir un programa sobre la base de trabajar el chisme como materia e identidad del programa, convirtiéndolo en un género televisivo. La gente no suele decir el nombre del programa, sino que es el chisme mismo su identificación" (Alfaro y Quezada, 2005: 90).

Pero, además, Magaly Medina aparece como personaje mediático de legitimación y verdad. No es producto del azar el hecho que Magaly Medina haya sido elegida, por medio de encuestas, como el personaje popular más poderoso (IPSOS-APOYO, 2008) e influyente 
en la opinión pública peruana (IPSOS-APOYO, 2009), como la figura de la farándula con más poder (IPSOS- APOYO, 2011), como la mejor conductora de la televisión nacional, y lo que es todavía más interesante, como una de las personas de mayor influencia y credibilidad del Perú (IPSOS-APOYO, 2012).

Y, precisamente por ello, es importante observar que el personaje que Magaly Medina, como la conductora del programa, construye por las noches, frente a las cámaras, en el set del estudio de televisión, espacio y tiempo donde los chismes y los ampays ${ }^{2}$ están subordinados al tono burlesco y un discurso imparable que

"siempre llama a cerrar filas con ella sobredimensionando las venalidades de sus víctimas, mofándose del exhibicionismo de los mismos artistas que persigue hasta el hartazgo, mostrándose intolerante con la paja en el ojo ajeno cuando luce frescamente la viga en el suyo [...] [cultivando] el palabreo con retórica gestual: diarios y revistas lanzadas al piso, poses de hueca indignación, generalizaciones abusivas, frases hechas. No cultiva la ambigüedad, pues tiende al fatalismo -'el huachafo de ayer es el huachafo de mañana, lo que empezó torcido no se enderezará jamás’- pero como este es el único antídoto contra la carga liquidadora del programa sobre su vida, no puede dejar de apelar a ella. Por eso no formaliza [ba] el romance con su productor Ney Guerrero, y, como Gisela, juega a la intertextualidad construyendo en el set un personaje de algún modo independiente del suyo (aunque insoluble de aquel) [...] [Es su discurso compulsivo y todas estas características las que se han] convertido en su tag de presentación y, más que eso, en metonimia y símbolo de su oficio" (Vivas, 2008: 485-487).

Pero, al mismo tiempo, lo que caracteriza a la conductora, con la cabellera teñida de rojo (sugerencia del difunto estilista limeño Marco Antonio) y aquella boca, que ha pasado por brackets y cirugías plásticas, fisiológicamente grande y desmedidamente abierta, cuando se mofa de todos y de todo, es una figura simbólica de independencia y autosuficiencia (proyectada ante cámaras y, a veces, fuera de ellas) que hace hincapié en el hecho de no depender sentimental ni económicamente de ninguna persona (tal vez, vale decirlo explícitamente: de ningún hombre). Así, pues,

"la conductora, desde su experiencia personal, reivindica el trabajo de la mujer pues se jacta de ser alguien que ha salido adelante siendo plenamente independiente. Del mismo modo, en su forma de conducir el programa, ella se muestra completamente autosuficiente, poderosa, insensible y altamente mordaz en sus comentarios. Domina con facilidad la escena y aparece como única líder y directora de su equipo de periodistas. Sin embargo, sus actitudes

2 Peruanismo que expresa el descubrimiento de algo o alguien que trataba de ocultarse. Originalmente es una interjección del juego infantil de las escondidas para avisar cuando un jugador descubre a otro (DRAE, 2001). 
de mujer moderna e independiente se ven empañadas con su imagen frívola. Asimismo, su imagen de mujer fuerte se asocia a sus reiterados gestos de desprecio ante los demás. En consecuencia, se construyen relaciones poco saludables entre el perfil de mujer moderna, independiente y fuerte con el retrato de aquella frívola y arrogante" (Alfaro y Quezada, 2005: 35).

Sin embargo, en la figura de Magaly Medina hay un hecho todavía más interesante. Aunque ella enfoca su discurso tanto en la vida del personaje como de la persona, el personaje de Magaly (en la esfera mediática) es abierto, mientras que la persona de Magaly (en la esfera pública y mucho más en la esfera privada) es resguardada con recelo.

Hablemos de la persona de Magaly Medina en la esfera pública. Y recordemos que son pocas las entrevistas que Magaly Medina ha dado a los medios de comunicación, pero cada vez que lo ha hecho, se ha encargado de recalcar y discutir textos literarios que afirma se encuentra leyendo en aquel momento. La literatura (como bien se sabe) se asocia simbólicamente, en el imaginario colectivo, a una minoría de clase alta, a un exclusivo y excluyente grupo culto, que practica (se piensa) un placer tan refinado y superior que le confiere a aquellos que lo realizan (o dicen hacerlo) un valor de superioridad y estatus.

En ese sentido, Magaly usa el símbolo de lo letrado no solamente como un modo de construcción de su persona en la esfera pública (no de su personaje), sino también como un modo de distinción. Y así como utiliza lo letrado para construir y distinguir su persona de su personaje, hay que sumarle a esto el hecho que viva en una zona simbólicamente exclusiva de Lima, que posea una casa en Miami y un yate, entre otros bienes inmobiliarios, así como una considerable acumulación de dinero. Estos otros símbolos también construyen un modo de distinción en el plano socioeconómico de la persona de Magaly Medina.

Pero así como Magaly Medina utiliza demarcadores de delimitación y diferencia en los planos social y económico, también utiliza su cuerpo mismo como un portador semiótico de construcción, distinción y diferencia de su persona pública para marcar y mantener una distancia delimitada en el plano racial. Y es que Magaly Medina ha ido cambiando, a lo largo de los años, su aspecto físico por medio de diversas cirugías plásticas. Se ha ido produciendo. Ha ido refinando (si esa es la palabra para intentar decir algo así como "desfeándose", puesto que ella misma juega, afirma y se burla de su fealdad física) poco a poco, lenta y casi inadvertidamente, las facciones de su rostro (su nariz, pómulos y dientes) y las formas físicas de su figura, gracias a la liposucción y a otras intervenciones en el quirófano.

Cabría, entonces, hacer la pregunta: ¿Se podría afirmar que la persona (no el personaje) de Magaly Medina se ha ido blanqueando? El metadiscurso corporal (hecho implícito) de la persona (no del personaje) de Magaly Medina sugiere que ella persigue un fenotipo sociomediático de belleza simbólica occidental e, implícitamente, sugeriría que ha ido superando, progresando, dejando atrás algo pensado como un estadio inferior, hecho que, entre otras cosas, plantearía una discusión de raza. 
Más allá de ello, es interesante constatar que tanto la persona como el personaje de Magaly Medina han sido producidos física y simbólicamente a tal punto que han terminado por convertirse en el paradigma de mujer desafiante, moderna y juvenil. Bailes en escena con sus dos pies izquierdos, vestidos deslumbrantes y jerga spanglish (el uso del Juat en vez del What) lo confirman.

Pero no sólo ella se construye, también construye a ciertos tipos de artistas. A través de la metonimia y el género construye identidades simbólicas como las chismosas y envidiosas, las mujeres en edad adulta, las "calabacitas" bonitas, las mujeres "movidas", las mujeres modernas y trabajadoras; los hombres libidinosos, los fracasados y los "mantenidos", borrachos y "tramposos" (ibidem: 33-35).

Y, por supuesto, los mismos artistas pasan también por un proceso de construcción de su imagen, donde muestran cómo quieren ser vistos. Muchos lo saben y, precisamente por ello, es que no dudan que la persona de Susy Díaz (cuyo personaje juega con la asociación "mujer-rubia tonta") sea inteligente o que la persona de Farid Odé (cuyo personaje juega con la asociación "hombre-mantenido") no sea mantenido, pues diferencian entre la persona y el personaje, donde la construcción consciente e intencional de este último les trae diversos y diferentes beneficios.

El personaje de Melcochita (ridículo para muchos) vende una imagen de hombre "tonto y gracioso", aunque el comportamiento de su persona en espacios públicos sea completamente distinto. Así, pues, se construyen imágenes de personajes para sacar ventaja dentro de un show system equilibradamente llevado y sostenido. Pero, si los artistas ganan valiosa presencia dentro de la vida mediática, ¿qué dan a cambio? Existe una suerte de pacto silencioso implícito (no necesariamente pacífica, como parte del juego) entre ambas partes, pues, por un lado, "Magaly TeVe" los pone en el espacio mediático, otorgándoles fama, pero, por el otro, los pone en ridículo, burlándose y satirizándolos.

¿Cabría, entonces, hacer la pregunta de si acaso este fenómeno no expresa ya una nueva forma de socialidad a nivel mediático de la aldea global en la era de la posmodernidad; en otras palabras, el eslogan (fantaseado) del manifiesto de la pragmática de la vida posmoderna: seamos operativos o desaparezcamos (Lyotard, 1979). En otras palabras, este fenómeno nos evidencia el hecho metonímico de que quien proyecta ciertas características las posee. $\mathrm{O}$, para enunciarlo desde el otro lado, de que uno tiene que renunciar a ser lo que no aparenta, pues debe haber una línea coherente entre la apariencia, la manera y el escenario. Y es que

"una vez que empezamos una actuación, tendemos a terminarla, y somos sensibles a las notas discordantes que pueden producirse en su transcurso. Si se nos sorprende en una tergiversación, nos sentimos profundamente humillados" (Goffman, 1993: 133).

De pronto, podemos constatar que el personaje y la persona también se construyen en su relación con la esfera mediática del personaje y la esfera pública de la persona. El persona- 
je de Melcochita es un hombre gracioso (transgresor) en la esfera mediática, mientras que la persona de Pablo Villanueva es un hombre serio (statu quo) en la esfera pública. Ahora bien, el personaje de Nataniel Sánchez es una señorita (statu quo) en la esfera mediática, en tanto la persona de Nataniel Sánchez es una mujer "movida" (transgresora) en la esfera pública. Pensemos en el caso de la actriz Nataniel Sánchez, captada en cámaras en la vía pública, junto a un hombre y dando signos de haber consumido alcohol. Y todo parece indicar que no hay nada más importante que la primera impresión.

“Sucede que algunos de estos accidentes menores y 'gestos impensados' están tan adecuadamente ideados para dar una impresión que contradice la fomentada por el actuante, que el auditorio no puede evitar alarmarse por estar comprendido en la interacción en un grado conveniente, aunque puede darse cuenta de que, en último análisis, el hecho discordante carece en realidad de significación y debería pasarse por alto. El punto crucial no es que la efímera definición de la situación causada por un gesto impensado sea en sí misma tan censurable, sino más bien que es diferente de la definición proyectada en forma oficial" (ibídem: 30).

Por ello, podemos afirmar que mientras más prestigiosa sea la persona, más se oculta su cotidianeidad, su lado humano, pues su significación, su personaje construido, se puede caer: "En tales momentos, el individuo cuya presentación ha sido desacreditada puede sentirse avergonzado, mientras los demás circunstantes se sienten hostiles, y es posible que todos lleguen a encontrarse incómodos, perplejos, desconcertados, experimentando el tipo de anomia que se genera cuando el pequeño sistema social de la interacción cara a cara se derrumba" (ibídem: 9).

Por el contrario, sucede que no nos preocupa cuando la persona es profana y nos tiene sin importancia el hecho de esconder los defectos. La primera impresión sobre Melcochita es una de carácter profano, por ello no preocupa su actitud en otro espacio, salvo que esta transgreda su propia transgresión, tarea mucho más difícil. Tal vez, por ello, en personajes como Melcochita o Susy Díaz, y quizá también hasta en la misma Magaly Medina, el castigo y la disciplina (aunque no la vigilancia) quedan anuladas, pues estos personajes son "casos perdidos": se han pasado ya al otro lado, son incorregibles o no quieren ser corregidos, pues no se avergüenzan de su estado transgresor; por el contrario, se burlan del mismo y hasta constituye un elemento estructurante de su personaje. Por otro lado, la primera impresión sobre Nataniel Sánchez es una de carácter sagrado (como encarnadora de un valor: en este caso, "señorita"), por ello su actitud transgresora en otra esfera de su vida cotidiana ocasiona que la significación construida por su personaje se caiga, se desmorone, o, por lo menos, que se ponga en duda. Y, por ello, la enunciación de la inconsistencia entre las imágenes dichas y hechas, sagradas y profanas, oficiales y no oficiales:

"Observamos con frecuencia que el individuo puede comprometer profundamente su yo, no solo en su identificación con un papel, un establecimiento y un grupo determinados, sino también en la imagen de sí mismo como alguien que no desorganiza la interacción social ni traiciona a las unidades sociales que dependen de esa interacción. Por ende, cuando se 
produce una disrupción advertimos que pueden llegar a desacreditarse las imágenes de sí mismo en torno de las cuales se forjó su personalidad [...] La vida puede no ser un juego, pero la interacción sí lo es” (ibídem: 133).

\subsection{La función social del chisme y el escándalo en "Magaly TeVe"}

Partiendo de una lectura de implicancias socioculturales, y aceptando su condición satírica, el propósito del programa "Magaly TeVe" no es ni la diversión ni el humor en sí mismos, sino la indignación y la desaprobación (expresadas con toda ironía, sarcasmo, parodia, exageración, comparaciones, analogías, dobleces, yuxtaposiciones posibles) contra alguien, ridiculizando sus costumbres, conductas, defectos, vicios y abusos que socialmente el sátiro o la sátira desaprueba mediáticamente. Así, la sátira burlesca constituye un medio para expresar la insatisfacción hacia un ser social-mediático. El contenido social de todos estos signos encuentra expresión en el chisme y el escándalo.

Son el chisme y los ampays que (en vivo y en directo) ventilan las intimidades, secretos y vergüenzas de la farándula local limeña; y los escándalos y la polémica que estos generan cuando rebotan mediáticamente en la prensa, los medios electrónicos y los otros programas televisivos y radiales dedicados, integra o parcialmente, al mundo del espectáculo, los que han hecho que el programa y su conductora, desde sus inicios, sean merecedores a críticas (tales como la de destructores de hogares y de ir en contra de la dignidad y la vida privada de las personas) y a ganarse enemigos, quienes resultan ser, por lo general, los mismos personajes víctimas de sus chismes y sus burlas verbalizadas, de las originales claquetas que aparecen antes y después de los comerciales y las frases burlonas debajo de la pantalla, y aquellos ampayados por las cámaras del programa, entre los cuales se pueden contar a futbolistas, actores, actrices, vedettes, cómicos, cantantes, presentadoras(es) de televisión y otros personajes del star system de la farándula local limeña ${ }^{3}$, figuras de la adoptada "ciudad de Chollywood", marca personal de "Magaly TeVe".

En ese sentido, para entrar en materia, vale señalar que el chisme

\footnotetext{
3 Entre muchos otros, el empresario Mauricio Diez Canseco, alias "Brad Pizza", ampayado con una bailarina cuando todavía estaba casado con la ex vedette Daysi Ontaneda. La actriz Celine Aguirre, ampayada junto al fotógrafo Domingo Giribaldi, hecho que la obligó a admitir, públicamente, que ya estaba separada del músico Miki Gonzáles. El futbolista Reimond Manco, ampayado dando una gran fiesta, hecho que motivó el descontento de los directivos del club Alianza Lima, al cual pertenecía. La modelo Viviana Rivasplata, ampayada en compañía del hermano del periodista y escritor Jaime Bayly. El futbolista Wilmer Aguirre, alias "Zorrito Aguirre", ampayado saliendo de una discoteca la noche anterior a un partido de fútbol. Las vedettes Martha Vásquez Chávez, alias "Yesabella", y Mónica Adaro ampayadas, supuestamente, en pleno ejercicio de la prostitución. El futbolista Tenchy Ugaz, esposo de la vedette Sara Manrique, ampayado saliendo de un hotel con una bailarina. La modelo Angie Jibaja, ampayada en Tingo María, ebria y orinando en la vía pública. La actriz y modelo Bárbara Cayo, filmada junto al actor Carlos Thornton en una situación comprometedora. La actriz y modelo Malú Costa, alias "Mamalú", ampayada dentro de un vehículo con el futbolista Aldo Olcese. El actor Lucho Cáceres, filmado protagonizando numerosos altercados callejeros. La actriz y ex reina de belleza Karina Calmet, ampayada en un romance clandestino, cuando se encontraba casada con el cantante Samir Bazzi.
} 
"ha estado presente en la televisión femenina desde que se asumió que el chisme era una debilidad mujeril a la que cabía dar rienda suelta en sus horarios reservados. Eran, entonces, chismes rosas de contenido y blancos de intención, circunscritos a embarazos dentro del matrimonio, fiestas, viajes y romances públicos [...] En breves secuencias, o en giros de entrevista, la conductora chismeaba con soltura pero con cautela. Los chismes más picantes e invasivos de la privacidad eran practicados por los asomos de prensa amarilla vespertina [...] en los cincuenta, pero estos no fueron fácil e inmediatamente asimilables por la televisión [...] La prensa del espectáculo, con amplio espacio para publicar los ecos noticiosos de la gente de televisión, tenía larga experiencia con el cotilleo pero no había dado el salto invertido a la pantalla. Salvo tímidos deslizamientos al chisme en la televisión mujeril y en los espacios de concursos, fue una novedad matinal que en 1997 Utilísima invitara sistemáticamente a redactores de diarios populares [...] Eran todavía, chismes inocuos, aunque más que antes, resbalando al terreno de los jales y 'congelamientos' profesionales, las crisis emocionales, las reacciones ante los picos altos y bajos del rating y los fugaces flirts de los chicos y chicas de telenovela" (Vivas, 2008: 483).

Ello hasta que el programa televisivo "Magaly TeVe" entró en escena:

"Este programa de chismes se caracteriza por hacer informes de la vida de artistas peruanos y extranjeros con un tono sarcástico. Se dedica a lo que comúnmente se llama 'raje', que no es otra cosa que hacer comentarios negativos enfocando las actuaciones deficientes de los artistas. Se regodean y divierten con los 'rajes' que derivan en insultos y apodos. El tono del programa refleja una actitud cizañera y muchas veces genera conflictos en la vida real de las personas involucradas -quienes no necesariamente detentan gran fama pero que están asociadas a alguien que sí la tiene o han ocasionado un gran escándalo-. Ser fastidioso y pleitista es el común denominador de los comunicadores del programa que también se descalifican entre ellos -es común que coloquen frases en la pantalla molestando a la conductora mientras esta dirige el programa-. Reiteradamente se da vueltas sobre un mismo lío causando una inevitable sensación de morbo. El programa va detrás de los famosos 'ampays' cuyo objetivo es revelar infidelidades, la homosexualidad de alguien, nuevas relaciones de pareja empañándolas de un halo negativo o el 'mal' comportamiento de ciertas chicas -calificándolas de 'movidas', 'jugadoras' y hasta de 'prostitutas'-. Difícilmente se reconoce el trabajo de alguien, menos aún se cree en cambios positivos o en buenas intenciones. Se producen reportajes y se hacen entrevistas a mujeres cuyas historias incluyen drogas, tragedias y escándalos" (Alfaro y Quezada, 2005: 32-33).

Pero, antes de profundizar en las virtudes del chisme, ¿se podría llegar a un consenso, por mínimo que este sea, sobre la noción de chisme o, en todo caso, sobre el acto de chismear? 
El chisme implica, como cualquier sistema de redes, una relación donde un sujeto (C) no presente se convierte en un objeto de comentarios valorativos por parte de un sujeto (A) que lo remite ya objetivado a otro sujeto (B).

Haciendo a un lado lecturas valorativas, es necesario insertar al chisme y el escándalo en una dimensión social, para comprender su función y, por lo tanto, su anclaje comunicativo. Parafraseando a Herskovits (1964 y 2007), el chisme, como fenómeno cultural, puede ser observado como un mecanismo que sirve no sólo para la (reiteración de la) unidad de los grupos, sino, y sobre todo, para el mantenimiento de lo moral dentro de un sistema sociocultural. En ese sentido,

"el chisme no tiene roles aislados en la vida comunitaria sino que es parte de la misma sangre y tejido de esa vida [...] Su importancia está indicada en el hecho que cada día, y por una gran parte de ese día, la mayoría de nosotros estamos enganchados en chismear [...] No obstante, comentarios populares sobre el chisme tienden a tratarlo como algo riesgoso y azaroso y usualmente como algo para estar en desaprobación [...] El chisme, en todas sus muchas variantes, es un proceso culturalmente determinado, que tiene sus propias reglas tradicionales, traspasa más allá de donde es fuertemente sancionado [...] El chisme, e incluso el escándalo, tienen importantes virtudes positivas" (Gluckman, 1963: 308).

Por un lado, "lo importante sobre el chisme y el escándalo es que generalmente son disfrutados por personas sobre otras con quienes tienen una relación social cercana" (ibídem: 313). Una relación social no necesariamente igual, socioeconómicamente hablando, pero sí una relación metonímica por proximidad (de la que además la misma Magaly Medina hace uso, hablando cara a cara, de tú a tú, con un lenguaje coloquial popular, con la seriedad jovial de una amiga que narra a una segunda persona). La interacción con los sujetos-objetos del chisme y de los chismosos se construye, entonces, a partir de una figura semántica de trasnominación, de relación por contigüidad espacial, temporal o causal. Así, no es casual que la gente que aparece en "Magaly TeVe" sea nuestra gente (Melcochita, Susy Díaz y no Brad Pitt o Richard Gere) a la que en algún momento podríamos tocar o cruzarnos en el supermercado.

Por otro lado, nos hace falta acercarnos (para terminar de entender las virtudes positivas del chisme) al acto mismo de chismear. Gluckman (1963) sostenía que el chisme mantiene la unidad y los valores de los grupos sociales, que permite a los grupos seleccionar mejor a los individuos que desean integrarse y que facilita la selección de líderes. Pero también sostenía que el chisme podía ser entendido como un arma social para poner a otro en su respectivo lugar. En ese sentido, como sucedía entre los indios Makah de la costa noroeste de Norteamérica, el uso de la lengua del chisme y del escándalo sirve para mantenerse cada uno en el lugar apropiado. Pero vayamos todavía más allá, y señalemos que

"Por lo tanto, cuando tratamos de comprender porqué es que las personas en todos los lugares y en todas las épocas han estado tan interesadas en el 
chisme y el escándalo sobre cada uno, tenemos que observar a aquellos a quienes excluyen de unirse al acto de chismear y de escandalizarse. Es decir, el derecho a chismear sobre algunas personas es un privilegio extendido sólo a una persona cuando esta es aceptada como miembro de un grupo [...] Por lo tanto, los derechos para chismear sirven como marcador de un grupo particular de otros. No hay manera fácil de poner a un extraño en su lugar más que comenzando a chismear: esto le muestra concluyentemente que él no pertenece" (ibídem: 313).

Se traza, así, una dicotomía entre los excluidos (los extraños y los que no pertenecen) y los que excluyen (miembros del grupo que chismea y se escandaliza). Pero, ¿de qué grupo estamos hablando? Ciertamente, del grupo que utiliza el chisme como una fuente de legitimación y verdad para juzgar el comportamiento público-privado del ciudadano famoso pero no ideal.

Los miembros (Magaly Medina, su equipo y los televidentes) de este grupo tienen la palabra (a través del chisme y el escándalo) para juzgar, ejerciendo su poder argumentativovalorativo activo de juicio. Mientras, los sujetos-objetos (los excluidos) se mantienen anulados y juzgados, sin poder contra-argumentativo, por lo menos en el instante mediático determinado por la duración del programa. Rescatemos, al respecto, que ya Durkheim (1982) señalaba que el ritual (y veamos los actos de chismear y escandalizarse como prácticas rituales) sirve como mecanismo de control social que integra a la sociedad y reproduce los roles y el estatus de su estructura social. Así, pues, culto a la sociedad y a la relación configurada de dependencia de la autoridad moral que tiene el individuo con su vida colectiva. Por ello, vale decir que

"la constante crítica, el chisme y las murmuraciones es una reafirmación de esos valores, que hoy en día no puede ser expresado de otra manera. Si reprimen el chisme y las murmuraciones, los valores mismos desaparecerían... [En ese sentido,] [...] el chisme dentro de un grupo lo diferencia de otros, tanto similares como diferentes [...] [Y] el escándalo es usado para mantener el principio de igualdad entre todos los miembros [moralmente ideales]" (Gluckman, 1963: 311).

Este sistema axiológico, donde valores y juicios son directrices conductoras para la interpretación y el pensamiento, no se remiten únicamente a construir los valorativos morales y estéticos, sino que edifican también las verdades científicas y observaciones cotidianas (Nietzsche, 2000), se reafirma a través del chisme y del escándalo, y se puede observar en la práctica social de una deontología del deber y de las obligaciones morales, como un poder judicial que se encarga de juzgar y sancionar, jugando el papel de ente regulador de la vida social en base a una teoría del deber-ser social o de cómo debe ser y no ser un ser social.

Es allí donde el chisme y el escándalo reafirman claramente los valores sociales del ser y del deber ser, y donde podemos comprender su función social en su dimensión cultural: 
"El chisme no muestra simplemente el interés general en las actividades, y las virtudes y los vicios, de otros, lo que caracteriza a cualquier grupo. El chisme pasa más allá de esta etapa y se convierte en escándalo vicioso, dirigido a demostrar que las demás partes no son dignas de ser [...] el chisme como un juego culturalmente controlado con importantes funciones sociales. [Y es que] mientras más exclusivo [en nuestro caso, deberíamos decir disciplinaria $=$ vigilante + castigadora $]$ es un grupo social [una sociedad, como la nuestra], más sus miembros encontrarán satisfacción en chismear y escandalizarse sobre uno y otro. Y más persistentemente repetirán el mismo chisme otra vez y otra vez y otra vez sin aburrirse" (Gluckman, 1963: 312-315).

Por un lado, una lectura denotativa nos sugiere que el chisme y el escándalo en "Magaly TeVe" se justifican en tanto que sostienen un discurso de re-uso: ese que nos dice que no debemos mentir y que mentir es malo (llámese a ello el no engañar a tu pareja sentimental o a otras personas en cuanto a quién eres o a lo que haces).

Una lectura connotativa, por otro lado, nos sugiere algo más: que el chisme y el escándalo en "Magaly TeVe" son parte de un aparato de educación disciplinaria.

\subsection{Vigilar y castigar desde el punto de vista antropológico}

Y ello a través de artefactos tecnológicos (las cámaras de seguridad, grabadoras de audio, cámaras de "Magaly TeVe", videograbadoras escondidas, cámaras fotográficas y de video de los teléfonos celulares, etc.) utilizados para que la inspección funcione "sin cesar. La mirada está por doquier en movimiento [...] Esta vigilancia se apoya en un sistema de registro permanente" (Foucault, 2002: 181).

De este modo, se puede sostener que "el sometimiento a 'observación' prolonga naturalmente una justicia invadida por los métodos disciplinarios y los procedimientos de examen. ¿Puede extrañar que [la imagen] [...] se haya convertido en el instrumento moderno de la penalidad?" (ibídem: 210). Recordemos que ya Heidegger (1938) apuntó que el fenómeno fundamental de nuestra época moderna es el mundo conquistado como imagen.

La imagen en "Magaly TeVe" deviene no sólo en artefacto de vigilancia, sino también, como futura evidencia y razón del castigo, en una fuente de verdad. ¿Evidencia de que la imagen es concebida como fuente de verdad objetiva, indiscutible, incorruptible y, sobre todo, imposible de ser manipulada, ya sea intencionalmente o no? De este modo, la imagen mediática no es concebida aquí como una construcción del mundo, ni siquiera ya como una representación de este, sino que es el mundo mismo, desenmascarado. Entonces, hablamos de un realismo ontológico, en el siglo XXI, que sostiene, todavía hoy, que la realidad existe independientemente a nuestra capacidad de aprehenderla. Así, pues, "Magaly TeVe" descubre y proporciona conocimiento sobre la realidad. 
Indirectamente, nos hemos acercado ya al hecho de un discurso normalizador. Y, ahora, nos encontramos en mejores condiciones para entender porque Magaly Medina juega con un papel de justiciera social, una especie de moral vigilante del ciudadano ideal en cuanto a la ética de su comportamiento, una suerte de panóptico humano. Magaly Medina es, en definitiva, una jueza de la normalidad. Pero una jueza de una normalidad muy singular: Magaly Medina, así como el programa que dirige, vigila y castiga todo comportamiento que atente contra (transgreda) la moral de un ciudadano del cual se espera docilidad.

"Magaly TeVe" es, pues, un espacio y tiempo mediático que existe (por medio de un pensamiento conservador burgués que valora la pureza, la limpieza, el control, y se opone, por ende, a la contaminación y al descontrol) por y para el orden de las normas sociales vigentes. Pues (lo sabemos) la axiología normativa y la normalidad son construcciones socioculturales. Y es que el discurso normalizador

\begin{abstract}
"permite al poder disciplinario ser a la vez absolutamente indiscreto, ya que está por doquier y siempre alerta, no deja en principio ninguna zona de sombra y controla sin cesar a aquellos mismos que están encargados de controlarlo; y absolutamente 'discreto', ya que funciona permanentemente y en una buena parte en silencio. La disciplina hace 'marchar' un poder relacional que se sostiene a sí mismo por sus propios mecanismos y que sustituye la resonancia de las manifestaciones por el juego ininterrumpido de miradas calculadas. Gracias a las técnicas de vigilancia, la 'física' del poder, el dominio sobre el cuerpo se efectúan de acuerdo con las leyes de la óptica y de la mecánica, de acuerdo con todo un juego de espacios, de líneas, de pantallas, de haces, de grados, y sin recurrir, en principio al menos, al exceso, a la fuerza, a la violencia" (Foucault, 2002: 164).
\end{abstract}

Así, Magaly Medina aprovecha su rol de personaje foucaultiano para cuidar y velar por la moral convencional llena de prohibiciones en espacios y tiempos públicos (prohibido engañar a tu pareja, prohibido intoxicarse en público, prohibido actitudes homosexuales, etc.) y ante las cuales la prohibición implícita más fuerte, y de las cual se desprenden todas las demás, connota la prohibición de mezclar la vida privada con la vida pública (empresa difícil de llevar a cabo ahora que cada día que pasa los mismos conceptos de lo público y lo privado van perdiendo sentido en sí mismos y están terminando por confundirse el uno en el otro). Y, por ello, la vigilancia es exhaustiva, permanente y omnipresente:

"El aparato disciplinario perfecto permitiría a una sola mirada verlo todo permanentemente. Un punto central sería a la vez fuente de luz que iluminara todo, y lugar de convergencia para todo lo que debe ser sabido: ojo perfecto al cual nada se sustrae y centro hacia el cual están vueltas todas las miradas" (ibídem: 161).

No es, al respecto, casualidad que "Magaly TeVe" pueda leerse como "Magaly te ve (a ti)": te está viendo, siguiendo, vigilando constantemente en la esfera pública (para castigarte en la esfera mediática), siguiendo cada paso tuyo, esperando pacientemente la equivocación 
social de uno. No obstante, este ejemplo humano de panoptismo público, encarnado en Magaly Medina, implica una congregación absolutista del poder y del ejercicio de juzgar y sentenciar, una mirada que vigila, pero que no es vigilada:

"Y para ejercerse, este poder debe apropiarse de instrumentos de una vigilancia permanente, exhaustiva, omnipresente, capaz de hacerlo todo visible, pero a condición de volverse ella misma invisible. Debe ser como una mirada sin rostro que trasforma todo el rostro social en un campo de percepción: millares de ojos por doquier, atenciones móviles y siempre alerta" (ibidem: 197).

En ese sentido, el ejercicio de la disciplina supone

"un dispositivo que coacciona por el juego de la mirada; un aparato en el que las técnicas que permiten ver inducen efectos de poder y donde, de rechazo, los medios de coerción hacen claramente visibles aquellos sobre quienes se aplican [...] unas miradas que deben ver sin ser vistas" (ibídem: 158).

Y siempre recordando que la disciplina

"no puede identificarse ni con una institución ni con un aparato. Es un tipo de poder, una modalidad para ejercerlo, implicando todo un conjunto de instrumentos, de técnicas, de procedimientos, de niveles de aplicación, de metas; es una 'física' o una 'anatomía' del poder, una tecnología” (ibídem: 199).

"Magaly TeVe", pues, como un panóptico humano, realiza un examen del comportamiento social en los espacios y tiempos públicos. El examen, como herramienta disciplinaria, consiste en una prueba que implica "[...] una mirada normalizadora, una vigilancia que permite calificar, clasificar y castigar" (ibidem: 189). Entonces, el poder disciplinario se ejerce haciéndose invisible, pero con una visibilidad obligatoria sobre quienes se ejerce. El examen "caseifica" a cada individuo, hace de cada individuo un caso. Así, es precisamente el que se sale de la norma, de lo establecido, el que es registrado y descrito con mucha más rigurosidad, ejerciendo sobre este un mecanismo de control y dominación:

"El examen combina las técnicas de la jerarquía que vigile y las de la sanción que normaliza. Es una mirada normalizadora, una vigilancia que permite calificar, clasificar y castigar. Establece sobre los individuos una visibilidad a través de la cual se los diferencia y se los sanciona. A esto se debe que, en todos los dispositivos de disciplina, el examen se halle altamente ritualizado. En él vienen a unirse la ceremonia del poder y la forma de la experiencia, el despliegue de la fuerza y el establecimiento de la verdad" (ibidem: 171).

Es por y para ellos que se produce un discurso disciplinario, y donde el castigo del delito se justifica ya no como reparación o venganza, sino como útil para la prevención y manten- 
ción del cuerpo social. Así, la disciplina, a través de una vigilancia jerárquica (una mirada que ve sin ser vista), tiene y construye su propio sistema penal, por el cual se castiga las desviaciones que no respetan un orden artificial y natural: no va tras la expiación del individuo, sino por la corrección y la normalización. Por ello, califica, a partir de una oposición binaria básica (lo bueno y lo malo), ya no las acciones sino al individuo mismo. En el proceso del castigo, este se propone como una escuela pública (como maquinaria pedagógica) de lo que se espera del ciudadano dócil e ideal moral.

Hay transgresores, del orden preestablecido, de todo tipo: desde los que tienen presencia en otros espacios y tiempos socio-mediáticos (como los asesinos, en la "crónica roja"; o los protestantes, en la crónica política) pasando por los que no tienen presencia socio-mediática (ebrios, locos, "rateros" de la calle) hasta los que transgreden la moral urracoide de Magaly Medina pero, como los anteriores, no tienen presencia sociomediática (mujeres "movidas", hombres libidinosos, personas homosexuales o infieles en la esfera pública).

No obstante, si estas personas hacen lo mismo que los transgresores a los que "Magaly TeVe" les presta atención, ¿por qué no forman parte del programa? Pues, porque son simples individuos anodinos. Son, en todo caso, personas y no "personajes". Y es que Magaly Medina vigila a aquel que merece (es digno de) ser vigilado. Pero ni el programa ni su conductora le confieren a la persona el estatus de personaje digno de vigilancia. Este estatus es conferido mucho antes por otros medios de comunicación. La emblematización (ser personaje y no persona) es conferida en cuanto el ser ingresa a formar parte del star system local, donde por su exposición mediática se convierte en un signo referente para muchos (un ejemplo de ello es Nataniel Sánchez, como Fernanda de las Casas, en “Al fondo hay sitio”). Por ello, Magaly Medina la vigila. Porque, como signo socio-mediático, atrae y llama la atención.

Magaly Medina tiene, entonces, a través de un programa comparativo, donde pone en una balanza lo dicho y lo hecho, una tarea que cumplir: castigar la transgresión social partiendo por la exhibición socio-mediática (pública y masiva) del delito. Esta exhibición socio-mediática (pública y masiva) o chisme y ampay presenta un carácter de juego donde, precisamente por ser lúdico, está prohibido molestarse. Sin embargo, el chisme y el ampay connotan también una determinada relación entre Magaly Medina y los transgresores: la de vigilarlos, castigarlos y disciplinarlos.

Una de las cosas que Magaly Medina busca es controlar la acción del cuerpo, su conducta y comportamiento. No importa controlar lo que piensan los transgresores, pero sí lo que hagan. Pero lo que hagan en un espacio público, aunque sean prácticas de la vida privada de las personas y no ya de los personajes, ya que no se vigila ni castiga la violación de la prohibición en sí misma (engañar a la esposa), sino la violación de la prohibición en espacios y tiempos públicos (engañarla donde todos puedan ver el engaño). Por eso, es común escuchar frases como "si vas a hacer algo malo, hazlo bien", "tienes que saberla hacer" o "que no te vean". 
Y por y para ello, la vigilancia de las miradas y el castigo "urraquiento" de las imágenes. Por y para la vigilancia, el castigo y la disciplina del comportamiento pseudosocial. En ese sentido,

"el castigo disciplinario tiene por función reducir las desviaciones. Debe, por lo tanto, ser esencialmente correctivo. [...] El castigo disciplinario es, en una buena parte al menos, isomorfo a la obligación misma; es menos la venganza de la ley ultrajada que su repetición, su insistencia redoblada. Tanto que el efecto correctivo que se espera no pasa sino de una manera accesoria por la expiación y el arrepentimiento; se obtienen directamente por el mecanismo de un encauzamiento de la conducta. Castigar es ejercitar [...] El castigo, en la disciplina, no es sino un elemento de un sistema doble: gratificación-sanción. $Y$ es este sistema el que se vuelve operante en el proceso de encauzamiento de la conducta y de corrección" (ibídem: 166-167).

Entonces, ya podemos comenzar a pensar nuestra sociedad como la de la vigilancia:

"Nuestra sociedad no es la del espectáculo, sino de la vigilancia; bajo la superficie de las imágenes, se llega a los cuerpos en profundidad; detrás de la gran abstracción del cambio, se persigue el adiestramiento minucioso y concreto de las fuerzas útiles; los circuitos de la comunicación son los soportes de una acumulación y de una centralización del saber; el juego de los signos define los anclajes del poder; la hermosa totalidad del individuo no está amputada, reprimida, alterada por nuestro orden social, sino que el individuo se halla en él cuidadosamente fabricado, de acuerdo con toda una táctica de las fuerzas y de los cuerpos" (ibídem: 200).

Pero, para contradecir y complementar, al mismo tiempo, a Foucault, la nuestra es no sólo una sociedad de la vigilancia, sino también una sociedad del espectáculo. ¿Por qué decimos esto? Si el devenir-panóptico de "Magaly TeVe" permite que un individuo pueda vigilar a muchos otros, el devenir-tecnológico de la contemporaneidad permite que muchos de nosotros podamos vigilar a un individuo (o a muchos de ellos). En resumen, permite que todos seamos jueces, que todos tengamos el derecho de vigilar y castigar, y otros el deber de cuidarse, de guardar las apariencias. Así, pues, podemos sostener que la Antigüedad ha vuelto:

"La Antigüedad había sido una civilización del espectáculo. 'Hacer accesible a una multitud de hombres la inspección de un pequeño número de objetos': a este problema respondía la arquitectura de los templos, de los teatros y de los circos. Con el espectáculo predominaban la vida pública, la intensidad de las fiestas, la proximidad sensual. En estos rituales en los que corría la sangre, la sociedad recobraba vigor y formaba por un instante como un gran cuerpo único" (ibídem: 200). 


\subsection{Reflexión final}

Finalmente, ¿qué podemos constatar sobre el porqué y el cómo del éxito de la estrategia comunicativa de este fenómeno televisivo? Hagamos, entonces, una primera constatación. Es un elemento social el que se convierte en núcleo semántico de la estrategia discursiva de "Magaly TeVe": un código moral socialmente compartido. Es decir, "Magaly TeVe", como fenómeno mediático, se comunica recogiendo códigos morales válidos ya en nuestro tejido social.

Entonces, la moral es el núcleo semántico del discurso de "Magaly TeVe". La moral, por lo tanto, estructura semánticamente algunos mecanismos elementales de la propuesta comunicativa de "Magaly TeVe". Pero, primero, ¿en qué consiste este código moral socialmente compartido? Es convencional y conservador, lleno de prohibiciones en espacios y tiempos públicos, como la prohibición del adulterio, la prohibición de atentar contra las buenas costumbres y la tranquilidad, así como la prohibición de atentar contra una heterosexualidad normativa. Pero una segunda lectura connotativa sugiere que la prohibición de mezclar la vida privada con la vida pública es más bien un mandato por cuidar que una práctica inmoral se convierta en una acción pública, debiendo permanecer restringida (no combatida ni exterminada) a la esfera privada.

Esto nos lleva ya a una segunda constatación. ¿Cuál es el mecanismo mediante el cual el programa televisivo "Magaly TeVe" comunica su estrategia discursiva estructurada por el código de valores morales socialmente compartidos? Es decir, ¿cómo opera el contrato social moral en la práctica? Pues, a través del chisme como artefacto que trabaja para el mantenimiento del orden moral dentro del sistema social, demandando, así, poner a cada individuo en su respectivo lugar.

Así se configura el chisme como discurso normalizador que vigila y castiga todo comportamiento que transgrede y atenta contra una norma moral socialmente establecida. La corporización del chisme (como el destape visual del ampay, la exposición ante cámaras de portadas de la prensa sensacionalista o la verbalización del "raje" o cotilleo) es la retórica argumentativa que asegura el cumplimiento, en el espacio público, de un contrato social.

Por ello, el compromiso del público y de la comunidad de chismosos (no únicamente racional, sino también afectivo y emocional) por asegurar, en aras del acuerdo (mediante una retórica que privilegia lo social) y del cumplimiento de un contrato social moral común a todos ellos. El chisme, así, como la consagración que garantiza el contrato social sobre lo moral. Hay que recordar, para esto, que la función de la conductora del programa (Magaly Medina) dentro de este sistema social a escala es la de un estratega, representante del nosotros, que garantiza la aplicación y el cumplimiento del código moral social.

Nótese que esta interacción social es pragmática y funcional a la organización desde la moral y a la relación desde el chisme que se propone en el fenómeno televisivo "Magaly TeVe", una interacción disciplinaria: vigilar y castigar (a través del chisme y el escándalo) 
todo comportamiento personal y privado de los personajes mediáticos en espacios públicos que atente contra los códigos morales socialmente compartidos.

\section{Juntos pero no revueltos. Uso social de raza y clase en "Al fondo hay sitio"}

Desde su aparición y hasta la actualidad, el fenómeno televisivo "Al fondo hay sitio" (2009) se ha convertido en el programa más visto a nivel nacional ${ }^{4}$. Este hecho captó ya nuestra atención como científicos sociales. Pero a ello se le sumaba otro hecho: que se ha hablado mucho sobre "Al fondo hay sitio" en las redes sociales, en reportajes televisivos, en columnas de opinión de la prensa y en la vida académica, pero verdaderamente muy poco se ha dicho.

Esto convocó nuestra necesidad por recuperar el sentido, porque apenas nos sumergimos en el discurso de "Al fondo hay sitio" fue fácil constatar que hemos confundido, ingenuamente, inclusión con eventuales redenciones dentro de un marco de convergencia espaciotemporal de dos códigos culturales contradictorios y que permanentemente se relacionan e interactúan desde directrices de raza y clase.

Reiteramos que, si bien las pocas reflexiones académicas sobre este fenómeno televisivo hacen observaciones sobre la reproducción de estereotipos y la constatable diversidad cultural de Lima, ninguna de ellas habla (lo que sí hacemos en este texto) de que raza y clase funcionan como núcleos semánticos que configuran, por un lado, la construcción narrativa de la fotografía (movimientos de cámara y tipos de planos) y de la música (bandas sonoras), y, por el otro, una relación e interacción social determinada de poder y violencia simbólica entre sus personajes. Conviene, pues, argumentar nuestra propuesta.

\subsection{Poder y violencia en "Al fondo hay sitio"}

Desde hace mucho, la antropología y, en mayor medida, la semiología nos han enseñado que hablar de cultura es hablar de construcciones comunicativas basadas en estructuras de sentido. Pero, en el Perú, la historia es más compleja: no sólo convergen distintas culturas, sino que además unas sacan ventaja sobre otras de su posición dominante en la vida oficial. ¿Resultado de ello? La inflación de una cultura oficial y la marginación de otras.

En el Perú, la historia es una historia de poder. Los sucesos de Cajamarca (entre incas y españoles) no representaron únicamente un encuentro cultural, sino, y sobre todo, un

\footnotetext{
4 En el 2009 aparece "Al fondo hay sitio" en horario estelar. Su audiencia no sólo pertenece a un sector socioeconómico de la sociedad, sino a diversos sectores. Es el programa bandera de América Televisión y se transmite de lunes a viernes de 20:00 a 21:00 horas en horario prime time. Ya el mismísimo título de "Al fondo hay sitio" proviene directamente del discurso oral de las calles limeñas, de los cobradores de pasaje del transporte público (las combis) que hasta ahora espetan dicha frase cada vez que intentan decirle a aquellos que esperan a estos vehículos que adentro "siempre hay lugar para otro", aunque sea apretujando a los demás.
} 
choque de códigos culturales. De estructuras de sentido. Entonces, superioridad de uno sobre el otro. Dominación y conquista (Cornejo Polar, 1994). Y a pesar de que desde los años cincuenta del siglo XX, a razón de los procesos migratorios internos de las culturas de provincias a Lima, y de las nuevas tecnologías de información y comunicación, el poder no sea más beneficio de unos pocos, todavía se reproduce tanto en el imaginario colectivo como en el discurso oficial (Estado, medios de comunicación y escuela), el estigma del poder asociado a aquellos que han acumulado no sólo un capital económico, sino además a quienes han heredado genéticamente un color y rasgo racial específico y poseen un capital cultural occidental. En otras palabras, una minoría oficial y simbólicamente occidental que hubo detentado el poder en el Perú. Entonces, subordinación de los no semejantes. A pesar de que los no semejantes hayan sido y sean la mayoría.

De esta manera, la herencia de una raza (color y rasgo) y la acumulación de una clase (economía y cultura) como mecanismos de poder. Y es que para esta raza no basta ser "blanco", sino que además se debe tener rasgos fenotípicos de un individuo simbólico occidental. Y es que para poseer clase no basta con tener mucho dinero, sino que además se debe tener referentes culturales de Occidente como la filosofía, la ciencia, el arte y la literatura. Así, pues, la cultura (entendida como educación y civilización) y, por lo tanto, opuesta al salvajismo y la barbarie.

Pero el poder sólo es evidenciable a través de su ejercicio, de las prácticas y las estrategias construidas socialmente para ejercer violencia simbólica consciente contra alguien y con el objetivo de marcar distinción y distancia para la relación e interacción social entre el violentador y el violentado. Porque las relaciones de poder existen en la medida en que los individuos actúan a través del uso estratégico de mecanismos (como la raza y la clase) con el fin de generar efectos de subordinación. Núcleos semánticos que configuran acciones y representaciones. Núcleos semánticos que son eficaces en tanto significan y funcionan. Para entender el hecho social se requiere, pues, atender a la aplicación de estos núcleos a las lógicas sociales (Augé y Colleyn, 2004: 116).

Entremos, pues, en materia. Busquemos en "Al fondo hay sitio" lo que Toffler (1980) llamaba "sociósfera", es decir, una organización, relación e interacción social específica. Y cómo esta se encuentra configurada por el poder y la violencia desde la clase y la raza. Pero no gastemos páginas discutiendo inútilmente si "Al fondo hay sitio" es una telenovela, serie, comedia, melodrama o una mezcla de todos estos formatos. No intentemos buscarle un rótulo o una categoría que no explica nada en sí misma. Recordemos que ya Barthes (2009) nos había advertido no definir palabras, sino cosas. Porque una taxonomía rígida nos obligaría

"a sacrificar la riqueza de los signos en aras de una clasificación acaso estéril. Pero la taxonomía o clasificación de unidades a partir de pretendidas categorías universales suele oscurecer el objeto de estudio porque resulta muchas veces de escasa utilidad cuando nos enfrentamos al análisis del discurso. La fácil recurrencia a universales termina por no explicar nada y el análisis se convierte así en un discurso tautológico" (Biondi y Zapata, 2006: 121-122). 
No obstante, sí nos parece necesario ponernos de acuerdo sobre qué estamos hablando. Por ello, preguntémonos: ¿de qué trata "Al fondo hay sitio"?

"Su trama gira en torno a las desavenencias de dos familias, los Maldini y los Gonzáles, quienes viven una frente a la otra en Las Lomas, la más exclusiva zona de una Lima de ficción. Esto no tendría nada de particular, si es que no se detallan las diferencias entre ambos clanes. Los Maldini son un grupo familiar orgulloso, descendiente de italianos que hicieron fortuna y que viven en la mejor casa de esta parte de la ciudad. Los Gonzáles, en cambio, son una familia mestiza de condición humilde, pero trabajadora. Son migrantes venidos de Ayacucho, ciudad ubicada en la sierra del Perú y viven en una casa permanentemente a medio construir allí en Las Lomas, gracias al terreno que les regaló el fallecido patriarca de los Maldini y contraviniendo a los deseos de su propia familia. Los conflictos amparados en la comedia no se harán esperar, sobre todo porque cada quien desea imponer su modo de ser en este lugar" (Vásquez Fermi, 2011).

Y, precisamente por ello, recordemos que Foucault (2003) nos había advertido que cuando hablamos de relaciones de poder tenemos que hablar también de una posibilidad de resistencia mediante la cual el subordinado tiene la opción activa de responder ante la violencia del poder, porque "no se trata sólo del discurso vertical de los Maldini, lleno de ataques y de humillación hacia la condición de sus vecinos. Los Gonzáles tampoco se quedan atrás y tienen palabras nada halagadoras contra sus vecinos del frente" (Vásquez Fermi, 2011: 17), aunque siempre en respuesta ante los abiertos ataques de violencia simbólica de los Maldini-De las Casas.

Por ello, no olvidemos que el poder puede tener efectos peligrosos. Podemos decir que la raza y la clase se vuelven armas plenamente efectivas cuando ya no es necesario que el racista o el clasista las emita a través de su violencia simbólica, porque los sujetos violentados las han interiorizado, históricamente, y su poderoso efecto traza, ahora, sus accionares y pensamientos.

Un claro ejemplo de ello lo podemos observar en Nelly Camacho (Doña Nelly), la matriarca de la familia González. Típica vecina "metiche" del barrio. Con pretensiones de ascenso social. Mencionamos tres situaciones diferentes, pero con el mismo accionar. La primera: el cuadro que Doña Nelly tiene de sí misma en posición altiva, casi como si se tratase de una importante figura corporativa del mundo de los negocios de élite. La segunda: cuando tuvieron la oportunidad de manejar la empresa de los Maldini-De las Casas, tanto los hijos y nietos como ella misma se alienaron culturalmente (y no gnósticamente) de los códigos de comportamiento y vestimenta, entre otros, de una cultura hegemónica a la que se esforzaban por parecerse a la misma. Y la tercera: en más de una ocasión Doña Nelly señalaba que ella quería tratar a Francesca (la matriarca de la familia Maldini-De las Casas) de "igual a igual". 
Pero habría que preguntarse a qué posición de igualdad se refiere Doña Nelly. ¿A la posición de poder hegemónico (que los discriminan y los marginan) y a la cual no pertenece y quiere pertenecer? ¿O a su propia posición de subalterna? Su comportamiento y discurso, salvo cuando se emborracha, responden, más bien, a la primera interrogante.

Así, pues, veamos primero cómo la clase (como núcleo semántico) configura la construcción narrativa de la fotografía (movimientos de cámara y tipos de planos) y de la música (bandas sonoras). Uceda y Zacarías (2012) han señalado (con respecto al poder que ejerce la clase en la construcción de las representaciones) que para las escenas de la familia González se utilizan, mayormente, planos secuencia, movimientos bruscos y no finos; mientras que para las escenas de la familia Maldini-De las Casas se utilizan planos detalle, movimientos suaves y limpios. Desde una valoración occidental, allá los González y "el desorden”, acá los Maldini-De las Casas y “el orden”.

Por ello, es interesante la siguiente escena. En el 2013, apareció el fenómeno de Internet denominado "Harlem Shake", que consistió en videos virales de propias imitaciones de corta duración y donde un individuo enmascarado o disfrazado baila mientras su grupo realiza sus actividades hasta que (un cambio de ritmo y un corte en la pantalla) nos muestra a todo el grupo realizando movimientos similares y estrambóticos. En otras palabras, el orden y la calma invadidos por el desorden y el descontrol. Esto mismo es lo que sucedió en "Al fondo hay sitio" cuando los productores decidieron hacer una versión del "Harlem Shake".

El lugar no podría haber sido mejor elegido: la casa de la familia Maldini-De las Casas. Espacio y tiempo donde imperan el orden y la calma. Y, por supuesto, quienes llevan el desorden y el descontrol a este espacio-tiempo es la familia González. Invasión carnavalesca de máscaras de danzas folklóricas (la Diablada) y de animales de granja (un pollo), mientras que el hijo de la familia Maldini-De las Casas aparece en escena vestido de soldado romano. Allá, signos del desborde popular limeño. Acá, signos y referentes nostálgicos de un Occidente que ya se va.

De esta manera, una representación (estereotipada, por supuesto) de dos sectores culturales diferentes: uno que pierde espacios y tiempos ante la presencia y permanencia social de una creciente clase media y sus poderes adquisitivos y estructuras culturales de sentido:

"Los Maldini han hecho hasta lo imposible por sacar a sus vecinos de Las Lomas y volverlo, aquel lugar idílico que ellos creen que se merecen. Los Gonzáles, por su lado, han afirmado su deseo y derecho por quedarse en una propiedad que les pertenece legalmente. Su presencia ha trascendido también a otros espacios antes negados para ellos como el country club, los restaurantes, la casa de playa. Hay un sentido de invasión de estos 'otros' a aquellos lugares que antes no se imaginaban conocer. Los Gonzáles se sienten bien en donde están. Son los Maldini y los sectores que ellos representan, aquellos que se sienten hostigados" (Vásquez Fermi, 2011: 17). 
Pero la construcción narrativa de clase (capital económico + el capital cultural occidental) no se limita sólo a la fotografía, sino que también la podemos ver representada en formas institucionalizadas (títulos educativos) y en formas objetivadas: la vestimenta de diseñador o marcas reconocidas frente a la ropa barata, sin marca reconocida y/o autoconfeccionada; la vivienda acabada y adornada con pinturas, esculturas, libros y otros bienes simbólicos de Occidente frente a la casa estancada en el proceso de construcción, con paredes de ladrillos sin empastar y adornada con imágenes populares de Cristo, fotos de los miembros familiares y una bodega en el garaje y un salón de belleza en la sala, ambos informales y sin licencia; la lengua y su repertorio usados de modo simbólicamente culto frente un uso de la lengua vulgar, las jergas y dialectos populares no formales; y entre otras más, la comida y la música:

"Actitudes completamente opuestas frente a un mismo hecho: la comida. Mientras que la familia González es bulliciosa y estresante, la familia De las Casas se presenta como refinada [...] Además hay que indicar que en la comida no son los mismos platos, y se da oposición entre un plato típico (peruano) y un plato más bien 'europeo-occidental' (los huevos revueltos con jamón); y es que estas oposiciones apelan a los estereotipos presentes en el público para marcar las diferencias entre los de clase media-baja o provincianos y los de clase alta o capitalina. De este modo, tenemos el principal elemento de oposición en la historia, la cual es la disyuntiva entre el provinciano y el capitalino [...] La opción de mostrar y especialmente exhibir los alimentos por parte del mayordomo de la familia Maldini-De las Casas nos hace pensar varias cosas. La primera es la forma como muestra los potajes: los exhibe como si fueran una obra de arte, limpia el exceso de comida, acomoda todos los elementos para que estén en orden y en su sitio. Peter está contento con su obra. Luego se nos muestra un plano de la obra terminada: flores en la mesa, vasos y platos en su sitio, por fin la obra maestra está acabada y Peter -como el imaginario de un pintor- admira su obra, se encuentra satisfecho de ella [...] La banda sonora para esta primera parte descrita es una pieza de música clásica, la cual está reforzando la idea de elegancia y finura planteada desde el comienzo del análisis, además que ayuda a crear un ambiente de calma y paz, cosa que es opuesta en la otra escena, que no tiene una banda sonora, pero que la bulla y los gritos ayudan a crear una idea de la familia González" (Uceda y Zacarías, 2012).

Ahora, entremos a la estructura familiar. En el espacio-tiempo familiar de los Maldini-De las Casas podemos observar una organización vertical. En el espacio-tiempo familiar de los González podemos observar una organización horizontal. Y esa misma organización familiar se extiende, desde ambos lados familiares, a las relaciones e interacciones sociales fuera de los respectivos grupos a las socializaciones con los "otros". Observemos, por ejemplo, cómo la organización familiar de los González privilegia la combinación, mientras que la de los Maldini-De las Casas privilegia la subordinación. Observemos esto en el contraste entre el ama de casa González y el mayordomo Maldini-De las Casas: 
"La primera figura es representada por el personaje de Charito, quien vemos desde el inicio como una mujer que se dedica a las labores domésticas de la casa como el lavado de ropa o la cocina [...] sin embargo, su actitud frente al resto de la familia es de igualdad, ella forma parte de la familia como un miembro más, actúa de forma cariñosa con todos sus integrantes. En cambio, en la otra familia, tenemos un personaje muy refinado que tiene un trato de subordinado muy presente. Recordemos que Peter se dirige a los integrantes de la familia como: 'madame', señorita/señorito, señores, etc. A la matriarca de la familia se dirige con un vocablo francés que significa señora; el empleo de ese idioma se considera culturalmente como un idioma elegante y refinado" (ibidem).

Veamos ahora cómo la raza (como núcleo semántico) configura la construcción de un determinado modo de relación e interacción social de poder y violencia simbólica entre sus personajes. Recordemos que, históricamente, una minoría ha sido la que detentado el poder en el Perú: minoría oficial y occidental, minoría que poseía la hegemonía racial (herederos genéticos de un color y rasgo más o menos definidos) y la hegemonía de clase (un capital económico y los referentes culturales de Occidente). Así, pues, el poder asociado a una raza y clase específicas.

En ese marco, observemos qué sucede cuándo se cambia una variable de la ecuación Poder = Raza (color de piel blanco y rasgos fenotípicos occidentales) + Clase (capital económico y el capital cultural de Occidente). Observemos qué sucede cuando, en el centro mismo del poder, no sólo se retira su específica variable de raza, sino que además se la reemplaza por una variable de raza simbólica e históricamente subordinada.

Observemos el caso de Fernanda de las Casas e Isabella Maldini. Dos mujeres de la élite limeña. Fernanda de las Casas (hija de Isabella Maldini) ha iniciado un noviazgo con Joel González, muchacho de una clase y una raza diferente a la de Fernanda e Isabella. Fernanda intenta defender su relación, pero su madre (por el nuevo novio y por los símbolos a los prejuiciosamente lo asocia) imagina a Fernanda vestida y comportándose como una mujer andina, tal y como se la representa y se reproduce en el imaginario colectivo y en el discurso oficial (Estado, medios de comunicación y escuela) a través de las siguientes asociaciones: vistiendo "polleras", con el cabello trenzado en dos, con un mote marcado y exagerado; con un movimiento corporal desproporcionado y parecido al de los enfermos mentales e, incluso, al de los animales. Estereotipo cultural. Imposible negarlo.

Pero vayamos todavía más allá. Parece ser que (desde Isabella y sus semejantes) el hecho de relacionarse e interactuar con individuos de otras clases, ajenas simbólicamente al poder, no sólo cambia tu condición de clase, sino también tu condición racial. En otra escena, Isabella Maldini se entera de que podría ser hija de provincianos. Individuos que no se encuentran adscritos al poder hegemónico de raza y clase, y sí asociados a una raza y clase simbólica e históricamente subordinada. Mirándose en el espejo de su habitación, Isabella señala: "Yo no puedo ser hija de provincianos". Para después mirar el color de su piel en el mismo espejo. Y concluye: "Pero si yo soy blanca". 
En otras palabras, su discurso nos dice que en provincias no existe gente "blanca". Pero, y aún más alarmante, también marca distancia y diferencia. Allá los "no-blancos", acá los "blancos". Terminando de reafirmar, por asociación, no sólo el estigma de que los "noblancos/no-occidentales" de allá no pueden ser de la clase dominante (capital económico y capital cultural de Occidente), sino además la idea de que el poder continúa siendo privilegio de un grupo hegemónico, exclusivo y excluyente.

\subsection{Redención y convergencia. La otra "inclusión"}

Rescatemos la expresión latina deus ex máchina. Originada en el teatro grecorromano para designar la inesperada intromisión de un elemento externo al escenario y a la trama que resuelve la situación dramática que parecía irresoluble. Pero este elemento intromisor resuelve el conflicto dramático sacrificando la lógica interna y la coherencia del desarrollo narrativo. No es difícil, de pronto, constatar que la resolución de los conflictos de cada final de temporada de "Al fondo hay sitio" presenta este carácter intromisor y forzado, que rompe con su propia lógica y coherencia narrativa. Y con sus propios núcleos semánticos que permanentemente configuran las relaciones e interacciones sociales dentro del mismo. Y estos mismos núcleos semánticos desaparecen forzosamente en los últimos capítulos del final de cada temporada de "Al fondo hay sitio".

Asimismo, aparecen cosechadas relaciones e interacciones sociales que no han sido sembradas ni cultivadas en el tiempo. Para dar cabida a eventuales (y no permanentes) forzados "finales felices". Y, lo hemos dicho desde el principio, estas forzadas eventualidades (a las que se le suma nuestra fuerte tradición melodramática en la representación de las diversas identidades limeñas/peruanas) han llevado a muchos a pensar en inclusión, cuando de lo que se trata, en realidad, es de forzadas y eventuales redenciones dentro de un espacio y tiempo social donde convergen dos códigos culturales contradictorios y que permanentemente se relacionan e interactúan desde directrices de raza y clase; y, desde las mismas, donde una cultura oficial hegemónica y de poder discrimina y margina a las otras subalternas.

"En la tragedia antigua se había podido sentir al final el consuelo metafísico, sin el cual no se puede explicar en modo alguno el placer por la tragedia: acaso sea en Edipo en Colono donde más puro resuene el sonido conciliador, procedente de un mundo distinto. Ahora que el genio de la música había huido de la tragedia, esta murió en sentido estricto: pues ¿de dónde se podría extraer ahora aquel consuelo metafísico? Se buscó, por ello, una solución terrenal de la disonancia trágica; tras haber sido martirizado suficientemente por el destino, el héroe cosechaba un salario bien merecido, en un casamiento magnífico, en unas honras divinas. El héroe se había convertido en un gladiador, al que, una vez bien desollado y cubierto de heridas, se le regalaba en ocasiones la libertad. El deus ex máchina ha pasado a ocupar el puesto del consuelo metafísico" (Nietzsche, 2006). 
Sería ingenuo, pues, por forzadas y eventuales redenciones, caer en la apresurada afirmación de que "Al fondo hay sitio" trabaja a favor de la inclusión, tal y como algunos han señalado, ya sea porque así lo quieren o porque creen que así debe ser. Pero eso no hace que sea así. Por ello, independientemente a nuestros deseos, conviene constatar que "Al fondo hay sitio" no reconoce ni acepta las diferencias ni mucho menos presenta una apertura verdadera hacia la diversidad, todavía más cuando su productor (Efraín Aguilar) ha declarado, en varias ocasiones, que se trataba de una serie, efectivamente, racista y clasista (Peru.com, 2012). Y conviene también, en esta línea, no confundir "convergencia" con "inclusión". Que unos y otros compartan (no tanto porque quieren sino, más bien, porque deben) un mismo espacio y tiempo no quiere decir, automáticamente, que haya inclusión.

Al contrario, para Caroline Cruz, las manifestaciones de la convergencia en "Al fondo hay sitio" son el no-reconocimiento y la exclusión de la diversidad y las diferencias.

“['Al fondo hay sitio'] celebra la diferencia, pero, más bien, propone esta diferencia desde un lugar hegemónico. Las relaciones de poder entre las identidades representadas se reproducen para lograr explosivos choques entre los personajes [...] ¿Acaso estos personajes inicialmente frívolos se conmueven y dejan de dar la espalda a otra realidad social? ¿Aprenden unos de otros en un intercambio equilibrado? ¿O siempre estarán los ricos sobre los pobres? ¿Es la manera de reivindicar a la audiencia mayoritaria de la serie? Porque, si saliéramos de la ficción por unos minutos, el mensaje de la inclusión y de la tolerancia a la diferencia sería claro y positivo: las clases sociales se pueden mezclar; y, aunque hay dificultades y mucha oposición alrededor, con amor nada es imposible. Pero también hay otro mensaje, donde las relaciones de poder están intactas entre familias; por más amor que exista, la diferencia racial, social y económica nunca será tolerada sinceramente. Entonces, presenciamos una inclusión más light" (ápud Vásquez Fermi, 2012: 133 y 136).

Pero advertir la intromisión forzada del acto cristiano de redención, como elemento que resuelve los conflictos narrativos de discriminación y marginación a partir de la raza y clase, no sólo nos permite evidenciar que "Al fondo hay sitio" resuelve la permanente y constante exclusión con una eventual y forzada "inclusión", sino que además (y aún más peligroso) nos sugiere, implícitamente, que unos pueden ejercer violencia simbólica contra otros, porque, final y eventualmente, estos últimos serán redimidos, ya sea por Dios o por los mismos individuos que los discriminaron y marginaron. Entonces, clasismo y racismo como mediadores de las relaciones e interacciones sociales. Posiciones hegemónicas que discriminan y marginan por definiciones y no por acciones. Así, pues, imposibilidad de diálogo y de convivencia saludable y democrática. 


\section{Fuentes consultadas}

Alfaro, R. y Quezada Chávez, A. (2005). Atracción fatal: gritos y susurros de género en la pantalla peruana. Análisis de programación y consulta ciudadana. Lima: Veeduría Ciudadana.

Askew, K. y Wilk, R. (2002). The anthropology of media: a reader. Oxford: Blackwell Publishers.

Augé, M. y Colleyn, J. (2004). Qué es la antropología. Barcelona: Paidós.

Barthes, R. (2009). Mitologías. Madrid: Siglo XXI Editores.

Baudrillard, J. (1978). Cultura y simulacro. Barcelona: Kairós.

Bauer, R. (1964). "The obstinate audience: The influence process from the point of view of social communication”. American Psychologist, vol. 19, núm. 5, pp. 319-328.

Berkowitz, D.

_(2005). "Telling what-a-story. News through myth and ritual. The Middle East as Wild West". En Rothenbuhler, E. y Coman, M. (eds.). Media Anthropology. Londres: Sage Publications.

_(2000). "Doing double duty: Paradigm repair and the Princess Diana what-a-story". Journalism: theory, practice \& Criticism, núm. 1, pp. 125-143.

_(1992). "Non-routine news and newswork; Exploring a what-a-story". Journal of Communication, núm. 42, pp. 82-94.

Biondi, J. y Zapata, E. (2006). La palabra permanente. Verba manent, scripta volant: teoría y práctica de la oralidad en el discurso social del Perú. Lima: Fondo Editorial del Congreso del Perú.

Carey, J. (1988). Media, myths and narratives: Television and the Press (1988). Oxford: Sage Publications.

Círculo Lingüístico de Praga (1970). Tesis de 1929. Madrid: Alberto Corazón.

Cornejo Polar, A. (1994). Escribir en el aire. Ensayo sobre la heterogeneidad socio-cultural en las literaturas andinas. Lima: Horizonte.

Couldry, N. (2003). Media rituals: a critical approach. Londres: Routledge.

Dayan, D. y Katz, E. (1994). Media events: the live broadcasting of history. Cambridge: Harvard University Press. 
Debord, G. (2002). La sociedad del espectáculo. Madrid: Pre-Textos.

Díaz Cruz, R. (1998). Archipiélago de rituales: teorías antropológicas del ritual. México D. F.: Universidad Autónoma Metropolitana.

Douglas, M. (1994). El mundo de los bienes. Hacia una antropología del consumo. México D. F.: Grijalbo

Dumézil, G.

_(1973). Histoires romaines. París: Gallimard.

_(1971). Types épiques indo-européens: un héros, un sorcier, un roi. París: Gallimard.

_(1968). L'Idéologie des trois fonctions dans les épopées des peuples indo-européens. París: Gallimard.

Durkheim, E.

_(1986). Las reglas del método sociológico. México D. F.: Fondo de Cultura Económica.

_(1982). Las formas elementales de la vida religiosa. Madrid: AKA.

Eco, U.

_(2000). Tratado de semiótica general. Barcelona: Lumen.

_(1986). La estructura ausente: introducción a la semiótica. Barcelona: Lumen.

_(1984). Apocalípticos e integrados. Barcelona: Lumen.

_(1980). Signo. Barcelona: Labor.

_(1971). Las formas de contenido Milán: Bompiani.

Eliade, $\mathrm{M}$.

(2000). El mito del eterno retorno. Madrid: Alianza Editorial.

_(1999). Mito y realidad. Barcelona: Kairos.

_(1996).Patterns in comparative religión. Lincoln: University of Nebraska Press.

Festinger, L. (1957). A Theory of Cognitive Dissonance. Stanford: Stanford University Press.

Foucault, M.

_(2003). "Il faut défendre la société”. Curso en el Collège de France (1975-1976). Madrid: AKAL.

_(2002). Vigilar y castigar: el nacimiento de la prisión. Madrid: Siglo XXI.

Frazer, J. (2011). La rama dorada: magia y religión. México D. F.: Fondo de Cultura Económica.

Geertz, C. (2003). La interpretación de las culturas. Barcelona: Gedisa.

Ginsburg, F. y Abu-Lughod, L. (2002). Media worlds: anthropology on new terrain. Berkeley: University of California Press. 
Gluckman, M. (1963). "Papers in honor of Melville J. Herskovits: Gossip and scandal". Current Anthropology, vol. 4, núm. 3, pp. 307-316.

Goethals, G. (1981). The TV ritual: worship at the video altar. Boston: Beacon Press.

Goffman, E. (1993). La presentación de la persona en la vida cotidiana (1959). Buenos Aires: Amorrortu.

González Requena, J. (1999). El discurso televisivo: espectáculo de la posmodernidad. Madrid: Cátedra.

Graves, R.

_(2002). Los mitos griegos. Madrid: Alianza editorial.

_(2000). Los mitos hebreos: el libro del Génesis. Madrid: Alianza Editorial.

Havelock, E. (1996). La musa aprende a escribir. Barcelona: Paidós.

Heidegger, M. (1938). “Conferencia: La época de la imagen del mundo”. Dictada en la Sociedad de Bellas Artes, Ciencias Naturales y Medicina. Friburgo, Alemania.

Herskovits, M.

_(2007). Life in a Haitian Valley. Princeton: Markus Wiener Publishers.

_(1964). Trinidad Village. Nueva York: Octagon Books.

Hjelmslev, L. (1971). Prolegómenos a una teoría del lenguaje. Madrid: Gredos.

Hovland, C. (1949). Experiments on Mass Communication. Princeton: Princeton University Press.

IBOPE TIME (2010). "Magaly TeVe - Magazine”. Lima: Planner Central de Medios. Extraída el 17/VIII/2013 desde http://www.slideshare.net/PlannerPeru/magaly-te-ve-201

Imbert, G. (2003). El zoo visual: de la televisión espectacular a la televisión especular. Barcelona: Gedisa.

IPSOS-APOYO

_(2011). “Hábitos y actitudes hacia la televisión”. Lima: Informe Gerencial de Marketing (IMG). _(2009-2010). "Hábitos y actitudes hacia la radio y la televisión”. Lima: Informe Gerencial de Marketing (IMG).

_(2008). “Encuesta anual del poder”. Lima: Perú Económico.

_(2001-2008). “Hábitos y actitudes hacia la televisión”. Lima: Informe Gerencial de Marketing (IMG).

_(1995-2000). “Actitudes hacia la televisión". Lima: Informe Gerencial de Marketing (IMG).

Jakobson, R. (1967). Fundamentos del lenguaje. Madrid: Ciencia Nueva. 
Jenkins, H. (1992). Textual Poachers: Television Fans \& Participatory Culture. Studies in culture and communication. Nueva York: Routledge.

La Pastina, A.; Rego, C. y Straubhaar, J. (2004). "La centralidad de las telenovelas en la vida cotidiana de América Latina: tendencias pasadas, conocimiento actual e investigación por venir". Global Media Journal, vol. 1, núm. 1.

Lasswell, H. (1948). "The analysis of political behaviour: an empirical approach". The International Library of Sociology, vol. 35.

Lazarsfeld, P. (1948). The people's choice: how the voter makes up his mind in a presidential campaign. Nueva York: Columbia University Press.

Leach, E.

_(1978). Cultura y comunicación: la lógica de la conexión de los símbolos. Madrid: Siglo $\overline{X X I}$.

_(1976). Sistemas politicos de Alta Birmania: un estudio de la estructura social Kachin. Barcelona: Anagrama.

Le Bon, G. (2000). Psicología de las masas. Madrid: Morata.

Lévi-Strauss, C.

_(2011). Antropología estructural II. México D. F.: Siglo XXI.

_(2008). La alfarera celosa. Barcelona: Paidós.

_(2000). Mitológicas IV: el hombre desnudo. Madrid: Siglo XXI.

_(1997). Antropología estructural. México D. F.: Siglo XXI.

Lindlof, T. (2010). Qualitative communication research methods. Londres: Sage.

Lippmann, W. (2003). La opinión pública. Madrid: Cuadernos de Langre.

Lule, J. (2005). "News as myth: daily news and eternal stories". En Rothenbuhler, E. y Coman, M. (eds.). Media Anthropology. Londres: Sage Publications.

Lull, J. (1988). World families watch television. Newbury: Sage Publications.

Lyotard, J. (1979). La condition postmoderne: rapport sur le savoir. París: Les Editions de Minuit.

Maffesoli, M. (2004). El tiempo de las tribus. El ocaso del individualismo en las sociedades posmodernas. México D. F.: Siglo XXI.

Martín-Barbero, J. (1992). Televisión y melodrama. Bogotá: Tercer Mundo. 
Martín-Barbero, J. y Rey, G. (2000). Los ejercicios del ver. Hegemonía audiovisual y ficción televisiva. Barcelona: Gedisa.

Marx, K. (2010). El capital: crítica de la economía política. Antología. Madrid: Alianza Editorial.

McQuail, D. (1972). Sociology of Mass Communication. Middlesex: Penguin.

Morley, D. (1996). Televisión, audiencias y estudios culturales. Buenos Aires: Amorrortu.

Nietzsche, F.

_(2000). La genealogía de la moral. Madrid: EDAF.

_(2006, marzo 7). "El nacimiento de la tragedia en el espíritu de la música”. Extraída 15/

VIII/2013 desde http://losdependientes.com.ar/uploads/tdfrj3cn7c.pdf

Perú.com (2012, febrero 22). "Efraín Aguilar: 'Al Fondo hay Sitio es una serie racista"”. Extraída el 21/X/2013 desde http://peru.com/2012/02/22/entretenimiento/espectaculos/ efrain-aguilar-al-fondo-hay-sitio-serie-racista-noticia-43681

Peterson, M. (2003). Anthropology \& mass communication: media and myth in the new millennium. Oxford: Berghahn Books.

Propp, V. (1987). Morfología del cuento. Madrid: Fundamentos.

Real Academia Española (2001). Diccionario de la lengua española. Vigésima segunda edición. Extraída el 20/IX/2013 desde http://www.rae.es/drae/

Ricoeur, P. (1981). Hermeneutics and the Human Sciences: Essays on Language, Action and Interpretation. Cambridge: Cambridge University Press.

Rothenbuhler, E. y Coman, M. (eds.) (2005). Media Anthropology. Londres: Sage Publications.

Sartori, G. (2002). Homo videns: la sociedad teledirigida. Madrid: Taurus.

Saussure, F. (1945). Curso de lingüística general. Buenos Aires: Losada.

Schudson, M. (2005). "News as stories". En Rothenbuhler, E. y Coman, M. (eds.). Media Anthropology. Londres: Sage Publications.

Shinar, D.; Olsthoorn, J. y Yalden, C. (1990). Dis-membering and re-membering: An improved conceptual framework for the analysis of communications in socio-cultural change. Montreal: Concordia University.

Silverstone, R. (1988). "Television, myth and culture". En Carey, J. Media, myths and narratives: Television and the Press (1988). Oxford: Sage Publications. 
Spitzer, L. (1961). Lingüística e historia literaria. Madrid: Gredos.

Thompson, S. (1955). Motif-Index of Folk-Literature. Bloomington: Indiana University Press. Thussu, D. (2008). News as Entertainment: The Rise of Global Infotainment. Londres: Sage.

Toffler, A. (1980). La tercera ola. Barcelona: Plaza \& Janés.

Tuchman, G. (1978). Making news: a study in the construction of reality. Nueva York: Free Press.

Turner, V.

_(2001). From ritual to theatre: the human seriousness of play. Nueva York: Performing Arts Journal Publications.

_(1980). La selva de los símbolos: aspectos del ritual Ndembu. Madrid: Siglo XXI.

Uceda, D. y Zacarías, J. (2012). “Al fondo hay sitio: una apelación a los estereotipos”. La mirada de Telemo, núm. 8. Extraída el 29/V/2013 desde http://revistas.pucp.edu.pe/index. php /lamiradadetelemo/article/view/3504/3438

Vargas Llosa, M. (2012). La civilización del espectáculo. Lima: Alfaguara.

Vásquez Fermi, G.

_(2012). "Al fondo hay sitio: una mirada mediada e inclusiva a nuestras diferencias". En Dettleff, J. Representación e inclusión en los nuevos productos de comunicación. Lima: Pontificia Universidad Católica del Perú.

_(2011). "Al fondo hay sitio, una mirada mediada e inclusiva a nuestras diferencias". Extraída el 29/V/2013 desde http://confibercom.org/anais2011/pdf/150.pdf

Verón, E.

_(1987). La semiosis social. Buenos Aires: Gedisa.

_(1972). Conducta, estructura y comunicación. Buenos Aires: Tiempo Contemporáneo.

Vivas Sabroso, F. (2008). En vivo y en directo: una historia de la televisión peruana. Lima: Fondo Editorial de la Universidad de Lima.

Viveiros de Castro, E. (2010). Metafísicas caníbales: líneas de antropología postestructural Buenos Aires: Katz.

Zizek, S. (2010). Viviendo el fin de los tiempos. Madrid: AKAL. 